\title{
Introduction:
}

\section{Marxism and the Classics}

In this book I propose to apply what I characterize as a Marxist approach to several ancient Greek texts. For me, such an approach implies a simultaneous concern with the politics of artistic form and with a central ideological theme. That theme, which has largely determined my choice of texts, is inherited excellence - the ways in which ideas about descent from gods or heroes and about aristocratic origins play a central role and undergo significant transformations in texts that both reflect and constitute the Greek cultural heritage.

There is of course no innocence in my choice of the theme of inherited excellence. Contemporary debates over "nature versus nurture," ethnic difference, gender essentialism, sociobiology, and various other modern equivalents of social Darwinism have enormous consequences in concrete contemporary political struggles. At the same time, I am wary of suggesting a simple continuity between ancient Greek ideological struggles and contemporary issues that operate at a whole other order of complexity. ${ }^{1}$ I offer neither a full Foucauldian archaeology of

'There is a world of difference between the evolutionary speculations of Xenophanes or Democritos and the revolutionary consequences of Darwin's lif ework. For an exceptionably readable and intelligent account, see Clark 1984. For some of the more contemporary ideological struggles in which Darwin and ideas about inherited characteristics are a key factor, see Lewontin et al. 1984 and Gould 1981 . For a specifically Marxist exploration of some of these issues, see Williams, "Ideas of Nature" and "Social Darwinism" (1980: 67-102). The debate both within feminism and against feminism centered on concepts of nature is so extensive and intense that it would perhaps be folly to signal a few representatives; but there is a useful historical perspective in Merchant 1980 . See also Fuss 1989 and J. W. Scott 1988 . Marable (1983: 252-53) comments 
the concepts at stake nor a simple set of ancient origins, but I believe that the contemporary relevance of this theme emerges clearly.

I attempt neither complete readings of the texts nor complete coverage of all the ramifications of my theme, but $I$ have chosen texts in which the ideas about inherited excellence attract to themselves many traditionally central issues such as the nature of the Greek hero and the relations of gods to mortals or of individuals to communities. At key points the exploration of inherited excellence in turn leads to more contemporary issues such as sexual politics or the opposition between nature and culture. On the formal level, my texts include the major genres of epic, choral lyric, tragedy, and philosophical dialogue. I attempt to integrate my reading of the historical emergence of these forms with the shifting treatments of my central theme.

Between the Iliad of Homer and the Republic of Plato there are many other texts one might examine to support, amplify, or qualify any conclusions one might draw from the texts I have chosen. I particularly regret, for example, not discussing Sophokles' Ajax or Euripides' Electra or Herakles, in each of which ideas about inherited excellence figure prominently. I have tried, however, to suggest an approach rather than to exhaust the topic. The major drawback of a more narrowly focused traditional philological approach-one that might be called something like "Phusis: its roots and branches"-is that it precludes grasping the rich relations of this central theme with the full range of other ideological themes in the works where it occurs. ${ }^{2}$

Though I eschew the completeness of an exhaustive philological survey, I have chosen some of the major moments in any trajectory one might draw of this theme from Homer to Plato. I of fer only a severely abbreviated account of the period between the Odyssey and Pindar because of the paucity of complete texts germane to my theme. Nonetheless, I comment in some detail on relevant dimensions of Hesiod, whose texts, in my reading of the Odyssey, function almost as a running gloss. So too in my treatment of Pindar I discuss early lyric, the Presocratics, and Theognis. I touch on Hesiod and Solon in my analysis of the trilogy form apropos of the Oresteia. Rather extensive discussions of the Sophists are central to my chapters on Sophokles' Philoktetes and

on the neoracist efforts to seek a natural basis for the exploitation of one race by another in the work of Carleton Coon, William Shockley, and Arthur Jensen. Gould has ably commented on the reactionary thrust of sociobiology (in Montagu 1980: 283-90; see also Steven Rose's contribution, 158-170).

${ }^{2}$ This is not to suggest that $I$ have not learned much from more traditional philological or sociological works such as Beardslee 1918, Thimme 1935, Haedicke 1936, Heinimann 1965 [1945], Lacey 1968, Donlan 1980, or even Arnheim 1977. 
Plato's Republic. Moreover, for reasons that become clear later in this introduction, I include more detailed historical analysis than is generally fashionable today in studies of literary texts. Although variations on the theme of inherited excellence do not end with Plato, his Republic constitutes an appropriate terminal point for exploring a set of ideological and practical alternatives that reach a kind of crisis by the end of the fifth century - a crisis to which Plato responded with so radical a solution that subsequent debate must in some sense start with him.

\section{The Problem of Methodology in the Study of the Classics Today}

The issue of how to approach the classics is particularly vexed in public discussions and is at least potentially a troubling personal question for anyone who earns a living today by teaching the classics. The classics in the West today appear to face two obvious and not necessarily incompatible options. On the one hand, their study may be reduced to a purely antiquarian hobby, either by benign neglect or by selfconscious rejection on ideological grounds. A variety of progressive groups have rightly objected to being indoctrinated with an imposed canon of texts which, whatever their virtues, are strikingly elitist and misogynistic as well as more subtly racist. On the other hand, the classics have recently been subjected to yet another attempted appropriation by a new wave of reactionary ideologues-the so-called New Right. Though this is not the place for a full history of appropriations of the classics, in the light of this contemporary crisis it is worth recalling briefly a few historical markers in the career of classics as an ideological signifier. ${ }^{3}$

For a committed monarchist like Thomas Hobbes in the seventeenth century, the political influence of the classics was overwhelmingly progressive and as such utterly pernicious:

By reading these Greek, and Latine Authors, men from their childhood have gotten a habit (under a false shew of Liberty,) of favouring tumults, and of licentiously controlling the actions of their Soveraigns; and again

3Jennifer Roberts's intriguing examination of English views of Athenian democracy from the 1630 s to the late 194 os has appeared recently (1989). For early American appropriations, see Meyer Reinhold's "Introduction" (1975: 1-27). Turner's fine study, particularly his chapter "The Debate over the Athenian Constitution" (1981: 187-263), covers a wider range than the word "Victorian" in its title suggests. His work is put to good use in E. M. Wood's opening chapter, "The Myth of the Idle Mob" (1989: 5-41). 
of controlling those controllers, with the eff usion of much blood; as I think I may truly say, there was never any thing so deerly bought, as theseWestern parts have bought the learning of the Greek and Latine tongues. (1950 [1651]: pt. 2, chap. 21, 183)

Yet to a revolutionary Christian like Blake, the task of building a new Jerusalem "among these dark Satanic Mills" evokes a bitter condemnation of

the Stolen and Perverted Writings of Homer \& Ovid: of Plato \& Cicero which all Men ought to condemn... . Shakespeare \& Milton were both curbed by the general malady \& infection from the silly Greek \& Latin slaves of the Sword. . . . We do not want either Greek or Roman Models if we are but just \& true to our own Imaginations. ("Milton, a poem in 2 Books," Preface. Blake 1982 [1804]: 95)

Throughout the nineteenth century, classics played a significant role not only in training bureaucrats and imperialists but in reinforcing gender roles (Ong 1962; Fowler 1983). By the Victorian period, however, as Eagleton (1983) has reminded us, classics stood generally for a crumbling elitist cultural hegemony, one no longer adequate to the need of controlling the so-called rising classes: "The urgent social need, as Arnold recognizes, is to 'Hellenize' or cultivate the philistine middle class" (24). Eagleton also quotes from a study of English literature written in 1891 : "The people ... need political culture, instruction, that is to say, in what pertains to their relation to the State, to their duties as citizens; they also need to be impressed sentimentally. . . . All of this [Eagleton summarizes here] . . could be achieved without the cost and labour of teaching them the Classics"(25-26). The solution, as Eagleton goes on to show, was the invention of English literature as a central component of the middle-class liberal arts curriculum, leaving classics in the original as the prerogative of the elite schools.

Today the agenda of the New Right is to use the classics of Greece and Rome along with other classics of a specifically Western tradition to rephilistinize, so to speak, progressive forces in our society. I have specifically in mind the enthusiastic support of the classics by such figures as Allan Bloom (1987), who sees in the canon of "great books" a prestigious vehicle for repudiating the demands of women, people of color, gays, and workers for an education supportive of their aspirations to full humanity. ${ }^{4}$ Any sort of "relativism" is anathema to Bloom,

${ }^{4}$ For one classicist's assessment of Bloom, see Nussbaum 1987. I also wish to express my enjoyment of comments on Bloom by James Dee and Susan Ford Wiltshire at a meeting 
who assures us that "the claim of 'the classic' loses all legitimacy when the classic cannot be believed to tell the truth" (374). For Bloom, it seems, there can only be one truth, which, he repeatedly claims, is founded in nature. "The women's movement," he assures us, "is not founded on nature" (10o), and he invokes the most misogynistic moment in Aristophanes to support this conclusion (99). Similarly, William Bennett, while Ronald Reagan's secretary of education, tirelessly bounced around the country upholding his version of the classics to indict women's studies, black studies, film and popular culture studies, deconstruction-in short, any form of intellectual endeavor that offers a meaningful critical perspective on the hegemonic discourse (Franco 1985).

In the light of these unacceptable options, my project consists in opening to scrutiny dimensions of classical texts that have been thus eagerly appropriated for an allegedly univocal canon of Western "masterpieces"- works offered as quite transparent embodiments of eternal truths of "the human condition" or the "human essence." To suggest provisionally another perspective on the value of the classics, I quote here a few excerpts from Antonio Gramsci's analysis of the old educational system in Italy in the early part of this century. He views with a cold, ironic eye the class functioning of the access to classics and the essential arbitrariness of their constitution as the literally privileged educational vehicle:

The fundamental division into classical and vocational (professional) schools was a rational formula: the vocational school for the instrumental classes, the classical school for the dominant classes and the intellectuals.... The technical school... placed a question mark over the very principle of a concrete programme of general culture, a humanistic programme of general culture based on the Graeco-Roman tradition. This programme, once questioned, can be said to be doomed, since its formative capacity was to a great extent based on the general and traditionally unquestioned prestige of a particular form of culture. (1971: 26-27)

At the same time, Gramsci singles out for praise in this older classical education the built-in invitation to make connections, an opportunity all too rarely realized in the teaching of classics today:

In the old school the grammatical study of Latin and Greek, together with the study of their respective literatures and political histories, was an educational principle-for the humanistic ideal, symbolized by Athens and

of the Classical Association of the Midwest and South (April 1988) and my appreciation for an opportunity to read some unpublished remarks by Norman O. Brown. 
Rome, was diffused throughout society. ... His [the male child's] education is determined by the whole of this organic complex, by the fact that he has followed that itinerary ... has passed through those various stages, etc. He has plunged into history and acquired a historicizing understanding of the world and of life, which becomes a second-nearly spontaneous-nature.... Logical, artistic, psychological experience was gained unawares, without a continual self-consciousness. Above all a profound "synthetic," philosophic experience was gained, of an actual historical development. This does not mean-it would be stupid to think so-that Latin and Greek, as such, have intrinsically thaumaturgical qualities in the educational field. (37-39)

Classics as a field of inquiry has no unique claim as the vehicle for teaching students how to integrate the "scattered limbs" of a culture, but at its best it is an excellent vehicle for critical exploration of how different aspect of a culture relate to each other. I believe that an approach, which I call Marxist, offers extraordinary advantages for such a critical appropriation of the classics. The ambiguities, however, which the term "Marxist" has acquired-not to mention the much heralded death of Marxism in Eastern Europe-might understandably suggest to some that it can be discarded as meaningless. My own perception is that the virulence with which the term is hurled as a mark of opprobrium and the ferocity with which it is claimed by some and denied to others indicate that the term itself is still very much a site of struggle. Particularly at a moment when the declarations of the end of Marxism are most strident, I am loathe to jump on that particular bandwagon. As someone who grew up in the 1950s, when demonstrations of the irrelevance of Marxism constituted a veritable branch of academic industry, I am as skeptical about claims for the irrelevance of Marxist methodology as I am about claims for the end of history.

\section{Orthodox Marxism}

Most of us grew up with what we thought was a pretty clear idea of what "Marxist" meant. It meant, above all, economic determinism. In this perspective, the mode of production is all important. The mode of production consists of two elements: first, the forces of productionthe sum of the available technological and human means for the support of human life through the exploitation of nature; and second, the relations of production-the social relations of human beings resulting from the organization of that production. These two elements together constitute the determining base or inf rastructure of a society. Political, 
legal, religious institutions and beliefs, arts, philosophy-culture in general-all are envisioned as a superstructure, more or less passively dependent on and determined by this base. ${ }^{5}$ Since in all known historical societies the relations of production involve profoundly unequal distribution of work, power, and privilege, social relations amount to class relations of an inevitably antagonistic character. Thus, within this superstructure, ideas-whether set forth in works of art or abstract theory or promulgated by various institutions within the society, constitute ideology, which simply reflects these base structures distortedly as in a camera obscura. ${ }^{6}$ The degree of the distortion itself is a direct consequence of the class interests of the propounders of the ideas-the ideologues. These elements-mode of production, forces and relations of production, base and superstructure, class, ideology and reflection-constitute the chief thematics of orthodox Marxism.

Marxist historiography in this older sense was concerned first of all with the periodization of the past and the characterization of societies in terms of modes of production: primitive communism or tribal society, the Asiatic mode or Oriental despotism, the ancient or slaveholding mode, feudalism, capitalism, and-if the future turns out right-communism. ${ }^{7}$ Once this periodization is granted, the content

${ }^{5}$ Marx's classic statement of the base/superstructure dichotomy is in the preface to $A$ Contribution to the Critique of Political Economy (1859): "In the social production of their existence, men [human beings] inevitably enter into definite relations, which are independent of their will, namely relations of production appropriate to a given stage in the development of their material forces of production. The totality of these relations of production constitutes the economic structure of society, the real foundation, on which arises a legal and political superstructure and to which correspond definite forms of social consciousness." $M E C W$ 29:263. Note that the superstructure in this formulation has two aspects: the legal and political aspects, which Marx seems to recognize as themselves institutions and practices, and corresponding forms of consciousness, which Althusser (1971: 127-93) insists are equally embodied in material institutions and practices, that is, "ideological apparatuses of the state." [Whenever possible I cite Marx from the stillappearing $M E C W$. I have found no translation that is sensitive to the sexist use in English of "men" or "man" for human beings in general. I have checked the German only of the Economic and Philosophic Manuscripts of I 844, the German Ideology, the Eighteenth Brumaire of Louis Napoleon, and Capital, vol. I (the most generalizing texts I cite). Marx consistently uses Mensch or die Menschen where translators use "man" or "men" in the (sexist) generic sense.]

${ }^{6}$ The phrase camera obscura was applied by Marx and Engels in the German Ideology $(1845-46)$ to the distorted image of reality presented in all ideology: "If in all ideology men and their relations appear upside-down as in a camera obscura, this phenomenon arises just as much from the historical life-process as the inversion of objects on the retina does from their physical life process" (MECW $5: 36)$.

${ }^{7}$ Marx and Engels first articulated the concept of a sequence of modes of production in the German Ideology (MECW 5:32-35), adding various refinements and modifications over the years. The Asiatic mode seems to have been the most tentatively proposed and most readily abandoned in subsequent theory, in part perhaps because it was understandably off ensive to Stalin (Treadgold 1987: 309). For a survey of the checkered history of the concept and an attempt to revive it on a new basis, see Godelier 1965: 2002-27 
of history consists, in the one hand, of detailed analyses of the level of technology (i.e., the most emphasized aspect of the forces of production) and, on the other, to cite the Communist Manifesto (1848), "the history of class struggles" (i.e., the relations of production): "Freeman and slave, patrician and plebeian, lord and serf, guild-master and journeyman, in a word, oppressor and oppressed, stood in constant opposition to one another, carried on an uninterrupted, now hidden, now open fight, a fight that each time ended, either in a revolutionary reconstitution of society at large or in the common ruin of the contending classes" (MECW 6:482).

The predictability of this sort of Marxism for classical studies is neatly illustrated by Chester Natunewicz's bibliographic survey of Eastern European classical scholarship (1975: 171-97; cf. 1971: 146-50). ${ }^{9}$ First, there have been elaborate studies of the slave mode of production. Discussions of slavery - with particular emphasis on rebellions or stirrings of discontent-have taken into account not only slaves but also gladiators, soldiers, provincials, the Romans' so-called allies, peasants, and urban masses. Literary studies have focused on the class role of authors and reflections of class struggle in their work, enlisting this or that poet, historian, or philosopher on the side of reaction or progress: Homer and Vergil, Plato and Thucydides are clearly "bad guys," whereas Epicurus and Lucretius-the chief representatives of ancient materialism-have been singled out for virtual canonization among socialist saints (Natunewicz 1975:174-75).

In English and American classical studies, this orthodox Marxism has been essentially all we have known until quite recently (Padgug 1975; Arthur and Konstan 1984). The work of Gordon Childe, Benjamin Farrington, Alban Winspear, George Thomson, and the Woods comes immediately to mind. I am concerned neither to correct it nor to defend it as such. The value of the questions such work poses in the scrutiny of Greek and Roman societies is in any case separable from the

and 1977: 99-124. For the role of the Asiatic mode in the debate over Marx's alleged europocentrism and unilinear developmental model, see Lekas 1988: 59-71. In his "Critique of the Gotha Program" (in Tucker 1978: 525-41), Marx breaks down the future communist society into two phases $(531)$, and this distinction is usually read as a distinction between a socialist phase and a true communist phase.

${ }^{8}$ It is worth underlining Marx's final phrase here as a corrective to those more exhortatory passages that suggest Marx's naive belief in the inevitability of progress. He knew too much history not to be aware of the real possibility that full-scale conflict could indeed lead to the common ruin of the contending classes.

9I should add that my sense of the predictability of this work, which I do not know firsthand, may derive in no small measure from Natunewicz's manner of presenting it. But we are much in his debt for his extensive labors in this apparently barren vineyard. The work of Andreev, some of which has been translated into German, suggests the sophistication possible within this framework. 
value of any specific answers these scholars may have offered. Indeed, no set of presuppositions can guarantee insightful or sophisticated results, but they can either open or bracket indefinitely whole sets of questions. The errors of George Thomson, for example, have been best pointed out by scholars essentially within that tradition, most recently G. E. M. de Ste. Croix (1981:41), who has brought his massive learning and considerable sophistication to bear in the finest demonstration to date of what this orthodox Marxism has to offer the study of ancient history. ${ }^{10}$ The most interesting qualifications in turn of some of Ste. Croix's conclusions have come from the equally orthodox Ellen Meiksins Wood (1989: 39-40, 121 ). ${ }^{11}$

Orthodox Marxism at its most mechanical, though committed to frequent citations from the authority of Marx himself where possible, owes far more to Engels's efforts to promote Marxism as a comprehensive, totalizing science equally relevant to the analysis of natural phenomena and of human social formations. ${ }^{12}$ To invoke nature as the

${ }^{10} \mathrm{~A}$ sampling of the reviews of Ste. Croix suggests just how vulnerable his will to orthodoxy has made his work to the heavy ironies of those classicists who are, we must assume, themselves quite free of any taint of ideology. Sealey (1982: 319-35) and Green $\left(1983: 125^{-26}\right)$ are not surprisingly the most savage and patronizing, saddling Ste. Croix with the horrors of Stalin and even Cambodia (a little historical background of this particular nightmare might at least spread the blame around a little more accurately; see Kiernan 1985). Badian (1982: 37-51), arguably the most prestigious of the lot, is also the most generous. While he too is full of heavy ironies at the expense of Ste. Croix's selfpresentation as "properly" Marxist, he is also able to acknowledge that "no other living scholar would be able to produce a book equal to its sweep" (47); "This is an impressive work, and not only in its vast sweep and in the numerous points of detail where Ste. Croix has seen more clearly than others" (50); "Like every major work of history, certainly of ancient history (one thinks of Grote and Mommsen) ... it is a work of passion" (51). But having put him in the class with giants, Badian is typical in insisting that whatever is valuable in the book is somehow in spite of its Marxism. Apropos of St. Croix's study of the decline of the Roman Empire, Badian declares, "This is the more persuasive the less we hear of strictly Marxist class analysis and the more we mix it with the simpler Aristotelian categories of the rich and the poor and with the status analysis of Finley" (50). In fact, one of the more telling theoretical arguments in Ste. Croix's book is his critique of Finley's preference for the Weberian concept of social status $\left(5^{8}, 85-96\right)$.

"Some might object that E. M. Wood cannot be called an orthodox Marxist because she attempts to attack the orthodox Marxist idea that the slave mode of production offers the best explanation of the historical phenomena of democratic Athens (1989: esp. $36-41$ ). What strikes me as more profoundly orthodox in her most recent book on Athens is her will to explain all political and cultural phenomena as determined quite directly by the class struggle at the level of production. For her more overtly polemical orthodoxy, see her attack on Poulantzas, Laclau, and Mouffe et al. in The Retreat from Class (1986).

${ }^{12}$ McLellan (1977: 102-4) notes a general split between, on the one hand, Marx's roots in Hegel and French socialism with a corresponding emphasis on politics, consciousness, and class struggle, and, on the other hand, Engels's concept of development based on technology more clearly inspired by Enlightenment thought and the direct experience of the Industrial Revolution in England. On the reasons for being wary of Engels, see also Lukács 1971 , discussed in the text. 
foundation for one's views has constituted (for quite a long time, as the ensuing chapters show) perhaps the most fundamental ideological gesture. ${ }^{13}$ The tendency, observable in Lenin, emerges in its most blatant and disastrous form in Stalin's pamphlet, a work alas long canonical among the Stalinist faithful, "Dialectical and Historical Materialism." This text begins with the declaration:

Dialectical materialism is the world outlook of the Marxist-Leninist party. It is called dialectical materialism because its approach to the phenomena of nature is dialectical, while its interpretation of the phenomena of nature, its conception of these phenomena, its theory, is materialistic.

Historical materialism is the extension of the principle of dialectical materialism to the study of social life ... to the study of society and its history. $(1940: 1)^{14}$

Marx here is turned on his head: an analytic method focused entirely on the phenomena of social life in history with passing metaphorical invocations of the laws of natural science is here presented as primarily an approach to nature and a study of society and history only by extension. The direct consequences of this perspective in the brutal quest for a purely technological solution to Russia's chronic underdevelopment and a savage enforcement of what soon became not just the party's but one man's version of scientific truth are essential components in the catechism of contemporary anti-Marxism.

In Marx's own historical context it is perhaps no exaggeration to say that no one could offer an analysis of any significant phenomena claiming serious attention without as well claiming for it the prestige of science. The Hegelian dream of subsuming empirical sciences under "absolute science" was swept away by the overwhelming triumphs of

\footnotetext{
13 It would not be an overstatement to say that a principal goal of Capital, subtitled $A$ Critique of Political Economy, is to refute the claims of classical economics that capitalism is natural by historicizing both capitalism itself and earlier accounts of its workings. One example must suffice: "One thing, however, is clear-Nature does not produce on the one side owners of money or commodities [Geld-oder Warenbesitzer], and on the other men [those sc. Besitzer] who possess nothing but their own labour-power. This relation has no natural basis, neither is its social basis one that is common to all historical periods" $(1967$ 1:169). An excellent, more contemporary statement of the role of nature in mystifying ideology may be found in Barthes' concluding essay of Mythologies (1972: 109-59).

${ }^{14}$ This work was published in 1938 as chap. 4 of Stalin's $A$ History of the Communist Party of the Soviet Union (Bolsheviks): Short Course; see Davies sub nomine in Bottomore et al. 1983: 460. See also McLellan, who rightly comments, "It would be putting it mildly to say that Stalin was no very subtle mind when it came to Marxist theory" (1979: 134). For a not very subtle defense of Stalin's theoretical contributions to Marxism, see Cameron 1987: 82-87.
} 
natural science. ${ }^{15}$ It is accordingly true that Marx was fond of invoking the notion of laws of economic change applying analogies from the physical and biological sciences. ${ }^{16}$ Marx was, however, quite clear that the sort of laws he envisioned are specific to each mode of production and therefore subject to historical modification. They are thus of an entirely different order from the laws posited about natural phenomena. ${ }^{17}$ Moreover, as Lukács rightly emphasized as early as 1923, the Hegelian core of Marx's political philosophy was the "dialectical relation between subject and object in the historical process" (1971: 3; his emphasis). ${ }^{18}$

Thus even within what could be called orthodox Marxism there existed a marked polarity between, on the one hand, a rigid scientism

${ }^{15} \mathrm{Cf}$. Taylor 1979: $136-37$ and Hegel's contrast between knowledge in anatomy ("a collection of items of knowledge, which has no real right to the name of science") and (true) philosophy (1967 [1807]: 67). Hegel subsequently argues that "true thoughts and scientific insight can only be won by the labour of the notion [Begriff]. Conceptions alone can produce universality in the knowing process. This universality is critically developed and completely finished knowledge" (128).

${ }^{16}$ In the first preface to Capital, vol. 1, for example, Marx speaks of the economic cellform, compares his work to that of a physicist, and alludes to the natural laws of capitalist production defined as "tendencies working with iron necessity toward inevitable results" (8). His "ultimate aim" is "to lay bare the economic law of motion of modern society" (10)-a clear allusion to Kepler, one of his favorite heroes (cf. McLellan 1973: 457). But even in this first preface it is clear that Marx found the scientific models of life sciences and Darwinian evolution far more congenial to his own Hegelian organicism than were the physical sciences. He defines his standpoint as one "from which the evolution of the economic formation of society is viewed as a process of natural history" and notes as a climactic point, "within the ruling class themselves, a foreboding is dawning, that the present society is no solid crystal, but an organism capable of change, and is constantly changing" (10). For Marx's interest in Darwin, see Letter to Engels, December 19, 1860

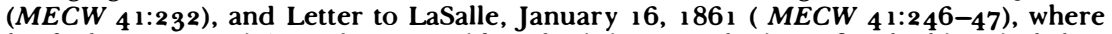
he declares, "Darwin's work ... provides a basis in natural science for the historical class struggle. One does, of course, have to put up with the clumsy English style of the argument. Despite all its shortcomings, it is here that, for the first time, 'teleology' in natural science is not only dealt a mortal blow but its rational meaning is empirically explained." See also Krader in Hobsbawm 1982 (192-226).

${ }^{17}$ Marx is more precise in his use of "laws" in his afterword to the second German edition (1873), in which he opposes through quotations from a Russian reviewer the rather platonic assumptions of classical economic theory that "the general laws of economic life are one and the same, no matter whether they are applied to the present or the past" (18-19).

${ }^{18}$ Failure to grasp this fundamentally dialectical character of Marx's thought leads Lekas (1988) to posit the most mechanically deterministic version of the base/superstructure dichotomy as the only truly Marxist view. Every departure from this mechanistic view in Marx's analysis of antiquity is then seen as an exceptional insight, contradicting and transcending Marx's own orthodoxy. It is striking in fact how many of the insights Lekas praises come from the Grundrisse, a lengthy, private, exploratory work in progress $\left(1857-5^{8}\right)$ at the same time as the composition of the very brief attempt at a simple summary, the preface to the Critique of Political Economy (1859), from which the canonical version of the base/superstructure dichotomy is drawn. 
obsessed with technology and claiming access to absolute truth by invoking transcendent laws, and, on the other, a more Hegelian tendency, focused on the history of human society and on the dialectic of human action and natural process, and committed to changing the rules of society's games. In this Hegelian sense, science is essentially serious, systematic knowledge worthy of being taken seriously.

\section{After Orthodoxy: Some Unorthodox Marxists (Including Karl)}

Although it would be too much to say that the burden of scient ism in orthodox Marxism has been discarded, nonetheless de-Stalinization (the 1956 invasion of Hungary, the 1968 invasion of Czechoslovakia, and persecution of Soviet Jews) and the recent breakup of the whole Stalinist empire have contributed progressively during the past four decades to the fragmentation of the Soviet-oriented organized left within the capitalist orbit and fostered a corresponding new openness in Marx-inspired thought. One should add that perceptions of the work of Marx and Engels themselves have been transformed, not only by these political upheavals but also by the publication and dissemination of texts heretofore lost or ignored such as the German Ideology, the Economic and Philosophic Manuscripts of I 844, and the Grundrisse, a massive collection of notebooks constituting preliminary sketches for Capital. ${ }^{19}$ The result has been a far more complex-more Hegelian, more humanistic-image of Marx, counterbalancing the relentless scientism usually associated with Capital.

In addition to Marx and Engels, major Marxist thinkers of the 1930 s who were either outside the orbit of Soviet orthodoxy or engaged in a

${ }^{19}$ The Economic and Philosophic Manuscripts of 1844 were first published in an incomplete form in Russian translation in Moscow in 1927. The first full edition of the German text appeared in 1932. The German Ideology, written during 1845-46, Marx and Engels, in their own words, "abandoned to the gnawing criticism of the mice." It was first published by the Marx-Engels Institute of Moscow in 1932. The Grundrisse, written in 1857$5^{8}$, was first published in excerpts in two volumes in 1939 and 1941 . The first full German text appeared in 1953. An English translation of the section entitled "PreCapitalist Economic Formations" with an excellent introduction by Hobsbawn was published in 1964. For an intelligent appreciation of the Grundrisse, see Nicolaus, "The Unknown Marx" in Oglesby 1969 (84-110), largely incorporated in Nicolaus's foreword to his Penguin translation (1973). $M E C W$ vol. 28 (1986) contains roughly the first half of the Grundrisse; vol. 29 (1988), the balance. It is no accident that, as noted above, most of the brilliant insights of Marx in which Lekas finds Marx contradicting Marxist orthodoxy come from the Grundrisse (1988, chap. 4). But a significant number also come from the posthumous vol. 3 of Capital, which hardly suggests that the Grundrisse represents a temporary aberration. For a brilliant and valuable attack-still haunted by the dream of Marxist "science"-on some consequences of the recent attention focused on the early works of Marx, see Althusser, "On the Young Marx" (1969: 49-86). 
virtual underground struggle within it have at last received a serious hearing in the wake of de-Stalinization. Antonio Gramsci meditated in a fascist prison on the experience of the Italian left in terms that have seemed far more relevant to many European and American leftists than inferences drawn from the Soviet and Chinese experiences. ${ }^{20}$ The Frankfurt School of Marxists, uprooted exiles from Nazi Germany, combined a profound interest in Freud and bourgeois sociology with a specifically Marxist sociology. ${ }^{21}$ Georg Lukács, alternately an apologist for and crypto-critic of the Soviet orthodoxy of "realism" in art, has received a more sympathetic reassessment in the post-Stalin era, and his early work has been recognized as itself one of the inspirations for the Frankfurt School. ${ }^{22}$ Ernst Bloch, a lifelong friend of Lukács, spiritually a member of the Frankfurt School but scorned for his Stalinism in the 1930s, became a significant inspiration for independent Marxists only in the 1960 s, after his conflicts with the East German government led him to ask for asylum from the West German government, which in turn found him a hard pill to swallow. ${ }^{23}$ Mikhail Bakhtin, whose book on Dostoevsky appeared in 1929 only after he had been arrested in a purge, was virtually unknown in both the East and the West until an edition of the Dostoevsky study was permitted to appear in the Soviet Union in 1963. After this point his works began to resurface amid a

${ }^{20}$ For an appreciation of Gramsci's contributions to Marxism, see especially Mouffe 1979, Sassoon 1982 and 1987 , Femia 1987 and Buttigieg 1986. In addition to the Selections from the Prison Notebooks (1971), two collections of Gramsci's political writings have also appeared (1977 and 1978 ) as well as a collection of his writings on cultural issues $(1985)$. See also the useful Reader by Forgacs (1988).

${ }^{21}$ For a useful collection of some basic texts, see Arato and Gebhardt 1978. For attempts at historical and critical assessments, see Jay 1973 and Held 1980. Jameson 1971 is primarily devoted to the work of the Frankfurt School but also includes discussions of Lukács, Bloch, and Sartre. Buck-Morss 1977 concentrates on Adorno's intellectual interactions with Benjamin but is full of insights on the whole experience and intellectual trajectory of the Institute for Social Research.

${ }^{22}$ For a sympathetic assessment that situates Lukács rightly within the general critical framework of the Frankfurt School, see Jameson 1971: 160-205. I also find Sontag's brief essay (1966: 83-92) on Lukács extraordinary for its time (first published in 1964). She rightly, in my view, celebrates the political philosopher of History and Class Consciousness over all the simplistic literary criticism that magisterially designates "good guys" and "bad guys" while virtually dismissing a serious encounter with most of the artistic production of the twentieth century. At the same time, her 1965 postscript, while rightly critiquing the inadequate theorization of form and content in Hegel-inspired, "historicizing" critics, seems to endorse a notion of the total autonomy of art from history and society that solves a problem by merely refusing it. For the specifics of Lukács's influence on the Frankfurt School, see Buck-Morss 1977: 25-28. Jameson in The Political Unconscious $(1981: 13)$ alludes to "the flawed yet monumental achievements ... of the greatest Marxist philosopher of modern times, Georg Lukács.” More recently, (1988b), he has again taken on the task of defending Lukács's contemporary relevance. See also G. Steiner 1970: 305-47 and Feenberg 1986.

${ }^{23}$ For a suggestive overview of Bloch's life and work, see Zipes's "Introduction" in Bloch 1988 (xi-xliii). See also Hudson 1982 and Jameson 1971 : 116-59. 
seemingly undiminished crescendo of enthusiasm in the West for his achievements. ${ }^{24}$ All these figures have in varying degrees contributed to and enriched the meaning of a Marxist approach to cultural analysis.

\section{Marxizing Alternatives to Marxism}

Several highly influential European intellectual developments, most notably structuralism, have clearly acknowledged their profound indebtedness to the writings of Marx (e.g., Lévi-Strauss 1974: 57-58; 1967: 340-41). Some have labeled themselves post-Marxists to indicate how much they owe to Marx's critical method but also to distance themselves from adherence to the alleged eternal verities and essentialism of orthodox Marxism. ${ }^{25}$ A similar ambivalence characterizes much political and cultural theory produced by feminists and those who define their positions primarily in terms of struggles against racism or for the environment: key aspects of Marx's analysis are seen as indispensable while others are rejected as untenable or potentially counterproductive. ${ }^{26}$ Ironically, then, the prestige of Marxism has risen dramatically from its nadir in the 1950s, but a new array of philo-

\footnotetext{
${ }^{24}$ For an account of the fortunes of Bakhtin's reputation, see Clark and Holquist 1984: vii-x.

${ }^{25}$ I refer especially to the paired work of Hindess and Hirst (1975 and 1977) and to Laclau and Mouffe 1985 . On the relation of Laclau and Mouffe to Marxism, see the lively exchange between them (1987) and Geras (1987 and 1988) as well as the far more sympathetic critique by Mouzelis (1988). The embarrassingly savage polemics of Geras and E. M. Wood (1986), though they occasionally score some points with which I would agree, seem so innocent of the Saussurean revolution that one often feels they are unaware of the very crisis to which post-Marxism, whatever its lacunae, seeks to respond. See also the work of French post-Marxists, whose titles are of ten indicative of their postMarxist posture; e.g., Baudrillard's The Mirror of Production (1975), Lyotard's The Postmodern Condition (1984), Nancy's La communauté désoeuvrée (1986) [ = "Community at Loose Ends"(?) - désoeuvrée is an untranslatable pun that also suggests the irrelevance of the category of work (oeuvre) and perhaps workers to any notion of community, which in any case is itself presented as a dangerous illusion], or Gorz's Farewell to the Working Class (1982).

${ }^{26}$ On feminism, see Firestone 1970: chap. 1; Hartmann in Sargent 1981 (1-42), as well as the extensive responses in the rest of that volume; Vogel 1983; Delphy 1984; Donovan 1985: 65-9o; MacKinnon 1982: 515-44; Hartsock 1983; Barrett (1988); and Nicholson in Benhabib and Cornell 1987. Barrett, once the most persuasive of "Marxistfeminists," has more recently espoused a position very sympathetic to Laclau and Mouffe (presentation at the annual meeting of the Modern Language Association, Washington, D.C., 1989). On Marx and issues of race, see Marable 1983. Hooks spans both feminism, and the black movement (1981 and 1984). On Marx and the environment, see Merchant 1980, Gorz 1980, and Weston 1990, which surveys recent leftist pronouncements on ecology and calls attention to the appearance of an impressive new journal edited by Marxist economist James O'Connor, Capitalism, Nature, Socialism. See O'Connor's theoretical introduction $(1988)$.
} 
sophically and politically compelling objections have increased the intellectual stakes in any explicitly Marxist critical endeavor.

Another consequence of these complex developments is that the term "Marxist," as a characterization of an approach to history, culture, and society, is by no means clear. In classics, the relatively orthodox work of Ste. Croix, while inspiring in some quarters the expected ire provoked by anything called Marxist, has been respectfully received by at least a few highly reputable non-Marxist scholars. Far more acceptable, however, to a broad range of American and English classicists is the rich output of post-Marxist Jean-Pierre Vernant and his associates, who in general have eschewed all labels. ${ }^{27}$ More relevant is the fact that the richness and sweep of the approaches they combine in their analyses presuppose a serious encounter with the work of Marx. But whatever their relationship to the Marxist label, it is no accident that such perceptive readers display such varying reactions and frequently deep ambivalence toward Marx. This is perhaps an inevitable function of deep tensions within Marx's own work-tensions concisely summed up by Maynard Solomon:

Marx's work arose in part as a reaction against the grandiose attempts at the systematization of knowledge by his metaphysical predecessors. His intellectual labors can be regarded as a perpetual tension between the desire to enclose knowledge in form and the equally powerful desire to reveal the explosive, form-destroying power of knowledge. Cohesion and fragmentation warred within him. It cannot be accidental that he brought none of his major system-building works to completion. (1979: 8)

Clearly, some of Marx's epigones threw themselves into what they perceived as the unfinished business of system building, while others responded primarily to the critical edge, from which Marxism itself is not immune. It is thus no surprise that Marx himself declared, "I am not a Marxist" (McLellan 1975: 78).

\footnotetext{
${ }^{27}$ For relevant bibliography, a fuller assessment, and warm appreciation of Vernant's work and its origins, see Segal 1982: 22 1-34). There is, however, no reference to the role of Marxism in Segal's essay. See also Arthur and Konstan's assessment of Vernant's influence on whatever there is of a left in American classical studies (1984: 59, 63, 65). Though Vernant himself might bristle at the label "post-Marxist," I intend it respectf ully and think there are real affinities between his critical position and theirs. In his essay "The Tragic Subject: Historicity and Transhistoricity" (Vernant and Vidal-Naquet 1988: 237-47) he is at pains to defend himself against the charge of non-Marxist ahistoricism; the doctrinaire source of the charge was specified in an oral version of this essay some years ago at Berkeley. On the other hand, it is not entirely surprising that a militant postMarxist such as Baudrillard repeatedly enlists the authority of Vernant's work in his own assault on Marx (1975: 82, 100, 101-102).
} 
Although I am wary of the aberrations of some twentieth-century Marxist system builders, nonetheless one of the deepest attractions of Marxism parallels Gramsci's grounds for admiring the old classical education-namely, its invitation to make connections, to bring some coherence to the understanding of phenomena that bourgeois analysis seems bent on keeping separate in ever more refined and narrow categories (academic departmental turfs and specializations are the most obvious instances). Lukács's defense of the methodological centrality of seeking to understand the social totality, "the total historical process" (1971: 9-10), still strikes me as a worthy aspiration, even if its full realization is impossible. Against the post-Marxists' ever more frantically expressed fears of totalization as automatically equivalent to totalitarian thought must be set the sheer hollowness and political impotence offered by a world of subtly differentiated fragments and deconstructed subjects. ${ }^{28}$ I believe that Marx himself of fered the best critique of pure "critical criticism" (the battle cry of the Young Hegelians) by his own shift in emphasis toward praxis, actions that change the rules of the game. There can be no activist politics without a ground ${ }^{29}$ even if one's ground turns out to be, as a black Christian Marxist has described Christianity itself, an "enabling metaphor." ${ }^{\circ}$ The provisional character of the Marxist explanatory model-its openness to and need for constant revision-must replace the old assertions of privileged access to a single, unmediated truth. The provisional character of one's efforts to approach the real must, however, be sharply distinguished

${ }^{28} \mathrm{Cf}$. Lyotard in The Postmodern Condition: "In communist countries, the totalizing model and its totalitarian effect have made a comeback in the name of Marxism itself" $(1984: 13)$. Derrida describes as his principle motivation in deconstruction "the analysis of the conditions of totalitarianism in all its forms, which cannot always be reduced to names of regimes" (1988: 648). This equation of totalizing with totalitarian, though not without historical grounds, is especially characteristic of the French post-Marxists and intimately connected, I believe, with the character of the Stalinist French Communist party. As Foucault remarked in a Telos interview, "since 1945, for a whole range of political and cultural reasons, Marxism in France was a kind of horizon which Sartre thought for a time was impossible to surpass. At that time, it was definitely a very closed horizon" (Raulet 1983: 197). Cornel West rightly sees the effort to deal with this problem as perhaps the central feature of Jameson's critical project (West 1982b: 179). This position is explicitly confirmed in one of Jameson's most recent publications, in which, commenting on the "demarxification of France" he gives voice to "the suspicion that at least a few of the most strident of the anti-totality positions are based on that silliest of all puns, the conf usion of 'totality' with 'totalitarianism.' I am tempted to conclude that what is here staged as a principled fear of Stalinism is probably of ten little more than a fear of socialism itself" (1988b: 6o). This article of fers a particularly compelling defense of taking seriously Lukács's articulation of the quest for the social totality from a contemporary, specifically feminist, standpoint.

${ }^{29}$ I owe this particular way of making the point to the late Linda Singer. But cf. Spivak apropos of Marx: "A purely philosophical justification for revolutionary practice cannot be found" (1984: 238).

${ }^{3 \circ}$ Cornel West, in conversation. But see West 1982a: esp. "Introduction." 
from a simple epistemological relativism; some models of knowledge have distinctly superior explanatory power. All models of knowledge have consequences for how one lives and acts.

\section{Marx and Utopia: The Quest for Realizable Freedom}

Because the critical model I apply involves-in its emphasis on the utopian dimension of Greek literature-a minority position even within Marxism, it may be helpful to indicate briefly how this emphasis relates to the work of Marx himself. The whole trajectory of Marx's work from his moving essay as a teenager on the choice of a profession (1835) through his doctoral dissertation on Democritus and Epicurus (1841) right up to his "Critique of the Gotha Program" (1875) is a discourse on the dialectic of necessity and human freedom. In this discourse the central struggle is simultaneously to grasp in all their complexity the barriers to freedom and to forge the means of smashing them. The content, so to speak, of human freedom in his vision owes a great deal to his direct knowledge of classical celebrations of the autonomy and space for full mental and physical development of the Greek free adult male citizen, a human being whose full individual development was clearly linked with his deep integration in a political community-especially in Classical Athens. To cite just one example from Marx's pervasive allusions to and echoes of classical texts (cf. Prawer 1978: esp. chaps. 1 and 2), here is a comment from a letter to Arnold Ruge written when Marx was twenty-five years old:

The self-confidence of the human being, freedom, has first of all to be aroused again in the hearts of these people [the Germans]. Only this feeling, which vanished from the world with the Greeks, and under Christianity disappeared into the blue mist of the heavens, can again transform society into a community of human beings united for their highest aims, into a democratic state. (MECW 3:137)

To be sure, Marx's vision was further enriched through his immersion in the Renaissance neoclassical ideal of the fully realized, fully developed courtier/prince/artist-l'uomo universale (Burckhardt 1958: 1:147-50). Thus for Marx, unlike William Blake, there was no contradiction between an almost obsessive love of Shakespeare-family readings of whom formed a major source of entertainment in the Marx household (Prawer 1978: chap. 3)-and love of the "silly Greek \& Latin slaves of the Sword." Finally, both these related ideals were distilled, elaborated, and updated for Marx in Hegel's vision of the fully 
conscious philosopher who is truly heir to the whole history of the human species. ${ }^{31}$

To present the whole goal of Marx's project as "work" or "labor" without explaining what these terms imply to Marx is to cut him off from both his classical and his Hegelian roots. ${ }^{32}$ Labor for Marx is emblematic of all expenditures of human energy, but the highest vision of that activity is the autonomous realization (i.e., making real in the material world) of specifically human desires and pleasures-discovered and affirmed in an open-ended, historical process of sensuous enrichment:

Only through the objectively unfolded richness of man's essential being is the richness of subjective human sensibility (a musical ear, an eye for beauty of form-in short, senses capable of human gratification, senses affirming themselves as essential powers of $\mathrm{man}$ ) either cultivated or brought into being. For not only the five senses but also the so-called mental senses, the practical senses (will, love, etc.) in a word human sense, the human nature of the senses, comes to be by virtue of its object, by virtue of humanized nature. The forming of the five senses is a labour of the entire history of the world down to the present. (Economic and Philosophic Manuscripts of I844, MECW 3:301-302)

Elsewhere in the same text Marx makes even clearer the open-ended, distinctly sensuous character of his vision of liberation: "The abolition of private property [i.e., capitalist property relations] is therefore the complete emancipation of all human senses and qualities, but it is this emancipation precisely because these senses and attributes have become, subjectively and objectively human" (MECW 3:300).

It is not uncommon to dismiss the utopian side of Marx as an early aberration corrected by the discovery of Marxist "science." On the contrary, the presupposition of the entire critique of capital is an ever-

${ }^{31} \mathrm{Cf}$. Lichtheim's attempt to sum up the originality of Hegel: "He remains the first thinker to have set forth the aim of representing in logical form the rise of consciousness as it gradually unfolds from bare sense-perception to Reason as absolute knowledge of the world and all there is in it. This unfolding is not simply that of the individual's selfeducation to philosophy. It is at the same time the record of Mind's long travail, for Man's self-education reflects and recapitulates the story of Mind's manif estation in nature and history" (Hegel 1967: xxxi-xxxii).

${ }^{32}$ The cliched versions of this critique rely on a literal interpretation of the phrase in the "Critique of the Gotha Program" (quoted in context subsequently in my text) "after labour has become not only a means of life but life's prime want." Baudrillard is only slightly subtler in always stressing the word "productive" or "production" in connection with Marx's concept of labor (1975: chap. 1). He acknowledges the element of the "esthetic of non-work or play" $(38-41)$ only to denounce it as a "bourgeois" holdover-as if he himself had some post-bourgeois alternative! 
deepening commitment to a largely implicit vision of an alternative social, economic, and political structure. The unpolished, unfinished capstone of his analysis, vol. 3 of Capital, contains a passage that clearly shows both the persistence of the quest for realistic liberation, for a $e u$ topia that is some place, and the depth of its grounding in an economic analysis. ${ }^{33}$ In this sense it forms the climax of the whole massive analytic effort. That climax is a tenaciously realistic opening of a vision of human freedom:

The actual wealth of society, and the possibility of constantly expanding its reproduction process, therefore, do not depend upon the duration of surplus-labour, but upon its productivity and the more or less copious conditions of production under which it is performed. In fact, the realm of freedom begins only where labour which is determined by necessity and mundane considerations ceases; thus in the very nature of things it lies beyond the sphere of actual material production. ... Freedom in this field can only consist in socialised man, the associated producers, rationally regulating their interchange with Nature, bringing it under their common control, instead of being ruled by it as by the blind forces of Nature; and achieving this with the least expenditure of energy and under conditions most favourable to, and worthy of, their human nature. But it nonetheless remains a realm of necessity. Beyond it begins that development of human energy which is an end in itself, the true realm of freedom, which, however, can blossom forth only with this realm of necessity as its basis. The shortening of the working-day is its basic prerequisite. (1967: 3:819-20)

A classicist might easily recognize the roots of this utopian vision in the visions first articulated in ancient Greece for adult male slaveowners. In particular, the anthropological speculations of the Presocratics and Sophists in which Nature cast as Necessity plays so decisive a role echo through the centuries in Marx's vision of necessity's persistence even in a regulated "interchange with Nature." There is, I believe, a further more general affinity between the relentless insistence in Marx on the material prerequisites to real freedom and the pervasive tragic realism of Greek reflections on human freedom from Homer to Aristotle. ${ }^{34}$

\footnotetext{
${ }^{33}$ Sir Thomas More called his imaginary island "Utopia" as a transliteration of a Greek-based neologism: ou = "no," and topia from Greek topos = "place." But, as Manuel and Manuel note, "in the playful printed matter prefixed to the body of the book the poet laureate of the island ... claimed that his country deserved to be called 'Eutopia' with an $e u$, which in Greek connoted a broad spectrum of positive attributes from good through ideal, prosperous, perfect" (1979: 1).

${ }^{34}$ Marxist sociologist Alvin Gouldner has appreciated this tragic realism in his focus on the "contest system" (1969). For his critical Marxism, see the eloquent obituary notice by J. Alt (1981: 198-203) and Gouldner 1980.
} 
Finally, in virtually the last serious political text Marx composed, his scathing Critique of the Gotha Program (1875), the dialectic between material prerequisites and a deeply classical utopian vision of full, free human development shines through: ${ }^{35}$

In a higher phase of communist society, after the enslaving subordination of the individual to the division of labour, and therewith the antithesis between mental and physical labour, has vanished; after labour has become not only a means of life but life's prime want; after the productive forces have also increased with the all-around development of the individual, and all the springs of co-operative wealth flow more abundantly-only then can the narrow horizon of bourgeois right be crossed in its entirety and society inscribe on its banner: From each according to his ability, to each according to his needs! (Tucker 1978: 531 )

Any vision of human freedom must be measured against the historically determined actual material constraints of freedom within which choices are made-choices that either limit or expand possible freedom. I would add that the qualitative possibilities of freedom under changed material conditions are a direct consequence of the quality of the whole preceding tradition of more limited visions. If it is true that "the tradition of all the dead generations weighs like a nightmare on the brain of the living" (Eighteenth Brumaire, MECW 11:103), it is also true that a better future requires achieving what "the world has long dreamed of possessing" (Letter to Ruge, MECW 3:144). Moreover, I take as literally true Marx's judgment that "the forming of the five senses is a labour of the entire history of the world down to the present" (Economic and Philosophic Manuscripts of I 844, MECW 3:302; cf. Vernant and Vidal-Naquet 1988: 239-42); a truly historical perspective on the cultural production of ancient Greece does not measure it in a simple scale against the visions of freedom realizable in our own time but analyzes its decisive pedagogical contribution to those very visions. Only a critical continuity with the rest of history offers the richest transcendence of what was possible in the past.

\footnotetext{
${ }^{35}$ It is often assumed that Marx's emphasis on human labor is entirely incompatible with the perspective of ancient Greece, where, we are repeatedly told, labor was disparaged. What was disparaged was in fact unfree labor-as in Marx. For an ancient Greek, as for Marx, unfree labor included both slavery and paid labor under the command of another. Without denying significant shifts in conceptualization, I would argue that the point of continuity between Marx's vision of free human labor and Greek ideals is the pervasive emphasis in the latter on autonomous, self-chosen action-the very core of Homeric and Sophoklean heroism. Moreover, the specifically fifth-century perception of the link between political freedom and the unleashing of human energies and capacities is a central component of Marx's vision. For elaboration of this latter point, see Chapter 6. For a recent orthodox Marxist attack on the "myth of the idle mob" in ancient Athens, see E. M. Wood 1989: chaps. 1 and 2.
} 


\section{Consciousness, Class, and Doing History}

Since a primary interest of my chosen texts is the way they both reflect and constitute consciousness, the issue of consciousness and ideological struggle centrally affects the senses in which I most of ten invoke the concept of class. Thus, although I do not dispute Ste. Croix's demonstration of the centrality of slavery in generating the surplus that made possible a highly self-conscious, leisured, ruling class, ${ }^{36}$ nonetheless the institution of slavery and the consciousness of slaves remains at best a "structured silence" (Macherey) or, as Fredric Jameson might say, the political unconscious in these texts. ${ }^{37} \mathrm{I}$ have more to say later about structured silences; but, for the most part, rather than focus my analysis primarily on filling in these lacunae in the texts, I focus on the aspects of class conflict that seem to me leave more readily perceptible symptoms in them. Most of ten these take the form of ideological struggle over the bases for justifying or questioning the existing social, economic, political, and sexual hierarchy. ${ }^{8}$ Moreover, however rooted the

${ }^{36}$ E. M. Wood (1989: 64-80) does launch a full-scale attack on what she sees as Ste. Croix's erroneous assumption that slavery was the only alternative to hired labor for extorting a surplus. She stresses among other factors the traditional role of rent in the panoply of means available to landed aristocrats for exploiting peasants. But see Ste. Croix, "Forms of Exploitation in the Ancient Greek World, and the Small Independent Producer" (1981: 205-75).

${ }^{37}$ Ste. Croix argues: "Actual slavery ('chattel slavery') . . . was the main way in which the dominant propertied classes of the ancient world derived their surplus.... The small free, independent producers (mainly peasants, with artisans and traders) who worked at or near subsistence level and were neither slaves nor serfs . . must have formed an actual majority of the population in most parts of Greece" (1981: 52). Lekas, citing Vernant, finds again in Marx's discussion of the ancient mode an insightful violation of Marxist orthodoxy; but though he rightly focuses on Marx's political analysis of class warfare in the polis, he goes too far in saying that rich and poor have no qualitative difference in relation to means of production (1988: 90-91). As Ste. Croix has demonstrated, it is precisely slavery that provides a qualitative as well as quantitative difference between rich and poor citizens. It is perhaps a vestige of M. I. Finley's own early exposure to a certain Marxism that the topic of slavery stands out as his most abiding concern-a point stressed by the anonymous author of his London Times obituary (June 26 , 1986).

${ }^{38}$ For the political aspect of class warfare in ancient Greece, see Ste. Croix's summary of enthusiastic endorsement of Aristotle's analysis of political activity in the Greek polis (1981: 71-80) and his "The Class Struggle in Greek History on the Political Plane" (1981: 278-326). Badian, in his review, accuses Ste. Croix of making Aristotle into a "proto-Marxist" (1982: 47) and himself seems to prefer the "simpler Aristotelian categories of the rich and the poor" $\left(5^{\circ}\right)$. The "advantage" of such categories is that they are often tacitly presumed to be constituted in isolation. The unpleasant notion that there are poor because there are rich and vice versa is absent from such categories-as it is from the minds of most contemporary ancient historians. At the same time, Aristotle's assumption that the motive force of so much of ancient Greek politics resides in the conflict of rich and poor is something of a sticking point, one would imagine, for those who want to banish any version of economy-related class conflict from their account of ancient Greece. 
conflicts between peasants and the ruling class may be in struggles over control of the economic surplus, the form in which those conflicts become conscious and are struggled over is more of ten linked to issues of social status, political power, gender roles, and ultimately epistemology. Accordingly, my analysis attempts to make connections among various sorts of struggles without being confined to a narrowly economic definition of conflicting groups.

The consequences of Marx's analysis of consciousness and class for the writing of history are substantially at odds with the ideal pursued by most practicing classicists. ${ }^{39}$ First of all, Marx's analysis of the fundamental link of ideas to the whole complex of realities subsumed under the concept of mode of production precludes the sort of fragmentation and specialization that for many are the marks of serious scholarship:

Morality, religion, metaphysics, and all the rest of ideology as well as the forms of consciousness corresponding to these ... no longer retain the semblance of independence. They have no history, no development; but men, developing their material production and their material intercourse, alter, along with their actual world, also their thinking and the products of

${ }^{39} \mathrm{Cf}$. Ste. Croix's citation from the preface of a recent book on Roman history of the usual cliches of alleged objectivity and freedom from irrelevant modern theories $(1981$ : 81-85; cf. 33-35). See also Fredric Jameson's meditation on a certain "antiquarian" practice in some approaches to classical antiquity: "Simple antiquarianism, for which the past does not have to justify its claim of interest on us, nor do its monuments have to present their credentials as proper 'research subjects' ... [but are] validated as sheer historical facts with the irrevocable claim on us of all historical fact-lead a ghostly second existence as mere private hobbies. One is tempted to say that this position 'solves' the problem of the relationship between present and past by the simple gesture of abolishing the present as such" (1979b: 45). Badian, in his review of Ste. Croix, shows his annoyance at the term "antiquarian," which he quite unf airly calls "his [Ste. Croix's] term for a specialist scholar" (47). The point of both Fredric Jameson and Ste. Croix (quite independently, I am sure) is not to disparage the intelligence or even the potential usef ulness of the type of work they so designate but rather to call attention to its relative naivete or disingenuousness about its own presuppositions. Every text has its unconscious, but the sort of scholarship they have in mind is self-congratulatory precisely about its own unconsciousness. Or, as Sullivan puts it, "there can be no un-ideological writing of history. The question is whether the historian is consciously aware of his approach and perspective" (1975: 6). The charge, central to Lekas's indictment (1988) of Marx, of imposing contemporary intellectual models on the past needs to be examined in light of the accusers' own accounts (usually missing) of the basis for any contemporary relevance available in the study of the past. There is a difference between asking questions of an ancient society that it would never ask itself and asking truly pointless questions. Moreover, for any answers about a different society to be intelligible to us, they must at least be cast in terms that are analytically productive for us. This is by no means to efface the difference between past and present; on the contrary, it theorizes difference as the most relevant object of inquiry. 
their thinking. It is not consciousness that determines life, but life that determines consciousness. (German Ideology, MECW 5:36-37) ${ }^{40}$

The goal toward which many of us classicists were trained to strive is to re-present as accurately as possible what the ancient peoples themselves actually thought and believed. This is precisely what Marx attacks:

The exponents of this conception of history have consequently only been able to see in history the spectacular political events and religious and other theoretical struggles, and in particular with regard to each historical epoch they were compelled to share the illusion of that epoch. . . . The "fancy," the "conception" of the people in question about their real practice is transformed into the sole determining and effective force, which dominates and determines their practice. (German Ideology, MECW 5:55)

Marx also posits an easy slippage from this kind of willing subordination to the self-conceptions of past eras into pure Hegelianism: ${ }^{41}$

The Hegelian philosophy of history is the last consequence ... of all this German historiography for which it is not a question of real, not even of political, interests, but of pure thoughts, which must therefore appear to Saint Bruno [Bruno Bauer, a leader of the Young Hegelians] as a series of "thoughts" that devour one another and are finally swallowed up in "selfconsciousness." (German Ideology, MECW 5:55) 42 $^{2}$

Marx's scorn of this approach is summed up in a climactic antithesis:

${ }^{4}$ The preface of a recent study of the Presocratics states with particular blatancy the author's (Hegelian?) faith in just the sort of total independence of philosophy's history to which Marx's alludes: "I do not believe that a detailed knowledge of Greek history greatly enhances our comprehension of Greek philosophy. Philosophy lives a supracelestial life, beyond the confines of space and time; and if philosophers are, perforce, small spatio-temporal creatures, a minute attention to their small spatio-temporal concerns will more often obf uscate than illumine their philosophies" (Barnes 1982: xii).

${ }^{41}$ Fowler, for example, points out $(1987: 4)$ the dependence of the whole Fränkel-Snell school on what is clearly a Hegelian notion of the Geist of an era. Cf. the Hegelianismarticulated with rare and praiseworthy explicitness-of MacCary (1982: esp. 16-25), whose whole project is tied to Snell and Fränkel (3). Jaeger's canonical Paideia (1945) is Hegelian in its whole conceptualization. This is by no means to suggest that these approaches are devoid of value - far from it - but to underline the extent to which so much work in classics still operates on Hegelian idealist assumptions challenged by Marx.

$4^{2} \mathrm{At}$ this point in the manuscript there is a marginal note by Marx demonstrating his sense of the close link between the two historiographical types: "So-called objective historiography consisted precisely in treating the historical relations separately from activity. Reactionary character" (German Ideology, MECW 5:55). 
Whilst in ordinary life every shopkeeper is very well able to distinguish between what somebody professes to be and what he really is, our historiography has not yet won this trivial insight. It takes every epoch at its word and believes that everything it says and imagines about itself is true. (German Ideology, MECW 5:62)

The alternative is sketched in terms which, for all the rhetorical emphasis on the primacy of production, insist on a dialectical reciprocity of the economic sphere with forms of consciousness and on the decisive role of revolutionary action in effecting structural change:

This conception of history thus relies on expounding the real process of production-starting from the material production of life itself-and comprehending the form of intercourse connected with and created by this mode of production . . . and also explaining how all the different theoretical products and forms of consciousness, religion, philosophy, morality, etc., etc., arise from it, and tracing the process of their formation from that basis; thus the whole thing can, of course, be depicted in its totality (and therefore, too, the reciprocal action of these various sides on one another) ... it . . explains the formation of ideas from material practice, and accordingly it comes to the conclusion that all forms and products of consciousness cannot be dissolved by mental criticism ... that not criticism but revolution is the driving force of history.... It shows that circumstances make men just as much as men make circumstances. (German Ideology, $M E C W$ 5:53-54, emphasis added)

\section{Marx and Cultural Production}

Marx himself did not produce a full-fledged theory of cultural production dealing with the whole range of complexities arising from art and literature. In this sense, "Marxist" approaches to these topics are only more or less credible extrapolations from the texts we have already considered together with a rich array of brief comments scattered throughout the corpus of Marx's surviving texts. ${ }^{43}$ Cutting short a potentially very long detour, I excerpt several issues arising from Marx's own wide-ranging analyses and explore a few twentieth-century elaborations more relevant to my own project. Most of the key issues in

\footnotetext{
${ }^{43}$ Solomon, who has an excellent brief selection from Marx and Engels at the outset of his own sweeping overview, notes that the collection begun in the 1930 s by Lif schitz and Schiller of all the relevant material comes in the German edition (Kliem 1967) to over 1,500 pages (1979: 5). In English, see Baxandall and Morawski 1973. Prawer 1978 offers an excellent overview of Marx's knowledge of and thoughts about literature. Demetz 1967 has useful material; its lacunae and distortions are ably criticized by Solomon (7-8).
} 
this area fall into significant, of ten overlapping polarities. On the one hand, art, insofar as it is a mere vehicle for class ideology, may transmit a class-bound, self-serving distortion of real conditions. On the other, as the "dream" which "the world has long been dreaming" and which only the future can bring to realization, as a decisive component in that "formation of the five senses" which is the "work of all history," art corresponds to the creative, mental activity that precedes all truly human accomplishments. As Marx put it:

a spider conducts operations that resemble those of a weaver, and a bee puts to shame many an architect in the construction of her cells. But what distinguishes the worst architect from the best of bees is this, that the architect raises his structure in imagination before he erects it in reality. At the end of every labour-process, we get a result that already existed in the imagination of the labourer at its commencement. (Capital, 1967: 1:178, emphasis added)

A classicist may recognize here an echo of Aristotle's use of the house builder in his discussion of the four causes (Physics $195^{b} 5^{-6}$ ), but the implications of the architectural metaphor are rather different in the context of Marx's preoccupations and ours. What is true of the labor process in general links the artist with all those who engage in any sort of productive labor. As Gramsci rightly insisted, there is no purely physical labor without some intellectual component (1971: 8-9). Artists, however, are among the generally privileged category of workers specifically charged with the task of reflecting on past human action and imaginatively projecting new structures of human thought, perception, and action. To be sure, the fact of their relatively privileged status suggests the likelihood of this process leading to self-serving consequences. But, to the extent that it posits a future different from the status quo, it contains a potentially liberating dimension by virtue of its implicit negation of that status quo.

Marx's own appropriation of the undoubtedly self-serving utopian visions of Greek male citizen slaveowners suggests that he was well aware that the same artist could perform both roles simultaneouslythat in the act of projecting a flattering and distorted image of the good life of the ruling class the artist makes available a discourse of freedom that can guide those excluded from freedom on a path toward actualization of a more gratifying future. The utopian visions of a narrow elite furnish guideposts for a struggle to extend that freedom to groups rigorously excluded from the initial vision.

I offer an example from postclassical history recently elaborated by post-Marxist thinkers: Laclau and Mouffe argue that the emergence in 
eighteenth-century bourgeois male ideologues of a doctrine of the "rights of man" (specifically, of white male property owners) made available a discourse susceptible of being fought over and for by women and people of color and in general by all those excluded from full rights (1985: 154-56).44 It follows from this line of argument that there is no necessary correlation between the artist's explicit or even implicit intentions and the full consequences of the work created either in its own moment or for posterity.

Moreover, in addition to this projective, utopian function of art, the artist quaideologue may serve a cognitive function. Like those ideologues of a dying class who perceive the real movement of history and align themselves with the rising class, the artist may serve a progressive educational function by presenting a truer image of the real conditions of society than is available from other sources. This artistic, critical negation of the status quo may occur independently of the artist's own personal political allegiances. Thus, for example, Marx was a great admirer of Balzac, whom he called "generally remarkable for his profound grasp of reality" (Capital, 1967: 3:39). According to Marx's sonin-law, Paul Lafargue, Marx considered that Balzac united both the cognitive and projective functions of the artist: "He considered Balzac not only as the historian of his time, but also as the prophetic creator of characters which were still in embryo in the days of Louis-Philippe and did not fully develop until after his death, under Napoleon III" (Prawer 1978:181).45

The noncongruity, then, of the author's class allegiance and his insights and the nonsynchrony of those insights and real conditions militate against the assumption of any simple equation of class position and artistic production or of art as nothing more than a reflection of the present circumstances. A Marxist historical focus on forms of consciousness thus implies neither complete immersion in the "illusion of the epoch" nor a mechanical extrapolation from the "material conditions."

\footnotetext{
${ }^{44}$ Laclau and Mouffe focus primarily on the origin of feminism, but they also note "the profound subversive power of the democratic discourse, which would allow the spread of equality and liberty into increasingly wider domains and therefore act as a fermenting agent upon the different forms of struggle against subordination" $(1985: 155)$. They call the emergence of a new vision of the human a "different discursive formation" (154) and are not specifically concerned with art. But their analysis is in this area quite consonant with the Frankfurt School Marxists' analysis of utopian thought.

45 Prawer notes in this context that Marx used Balzac's Crevel from La cousine Bette in an ironic compound, "Véron-Crevel," at the end of Eighteenth Brumaire (MECW 11:196) to suggest precisely that Louis Véron, the editor and owner of Le Constitutionel, was the real-life embodiment of Balzac's projective creation. It is amusing that the apparently still Stalinist editors of $M E C W$ assure us in a note that Crevel was "a character based on Dr. Véron." For them, life must precede art.
} 


\section{Mediation, Hegemony, and Overdetermination}

How then is one to "historicize" properly classical antiquity? I have already suggested the inadequacy for my purposes of Ste. Croix's impressive but quite orthodox Marxist version of the nature of class struggle. Admirable and subtle as are his discussions of most sorts of historical data, precisely when he touches on literary evidence he falls back on a simple reflectionism that characterizes not only most older Marxist but most historical approaches to literary texts (Rose 1988: 611). In attempting to move toward what I consider a more properly dialectical conception of the relation of the literary text to the economic, social, and political structures of ancient Greece, I have found among twentieth-century Marxists Bakhtin, Gramsci, Althusser, and Fredric Jameson to be most helpful. Because for my purposes his work incorporates and carries forward that of his predecessors in crucial new directions, I discuss Jameson in a separate section.

Bakhtin, assuming for the sake of argument-or for his own survival-the party's one-way reading of the determination of superstructure by the economic base, goes a long way toward subverting the model by suggesting some of the inevitable mediations in that process. Taking the example of an alleged connection of the image in a novel ("Rudin as superfluous man") with the degeneration of the gentry class, he notes,

even if the correspondence established is correct ... it does not at all follow that related economic upsets mechanically cause "superfluous men" to be produced on the pages of a novel. ... The correspondence established itself remains without any cognitive value until both the specific role of the "superfluous man" in the artistic structure of the novel and the specific role of the novel in social life as a whole are elucidated. (Voloshinov [Bakhtin] 1973: 18) ${ }^{46}$

Thus there is a logic internal to the specific work of art, and any interpretive enterprise must first give an account of how any particular element relates to that logic before exploring its social, political, or economic resonances. Second, Bakhtin indicates that we need to try at least to specify the politics of the particular form or genre in which such an element occurs - that is, what sorts of functions it performs in relation to what sorts of audiences.

${ }^{46}$ On the grounds for considering the work published under the name of Voloshinov to be in fact the work of Bakhtin, see Clark and Holquist 1984: 146-51. For a vigorous def ense of Voloshinov's authorship which gives me some pause, see Titunik's introduction in Voloshinov $1987(\mathrm{xv}-\mathrm{xxv})$. 
Bakhtin proceeds to elaborate other significant mediations:

Between changes in the economic state of affairs and the appearance of the "superfluous man" in the novel stretches a long, long road that crosses a number of qualitatively different domains, each with its own specific set of laws and its own characteristics. ... the "superfluous man" did not appear in the novel in any way independent of and unconnected with other elements of the novel, but ... on the contrary, the whole novel, as a single organic unity subject to its own specific laws, underwent restructuring, and ... consequently, all its other elements-its composition, style, etc.also underwent restructuring. And what is more, this organic restructuring of the novel came about in close connection with changes in the whole field of literature, as well. (18)

I would wish to distance myself somewhat from the apparent formalist assumption here of an inherent unity in the literary text, but Bakhtin rightly argues that any alleged element in the work under discussion must be examined in terms not only of the way it is affected by the specifically literary character of its context but also of how it correspondingly affects the whole of that extraliterary context. In turn, he enjoins us to keep in mind how the specific literary text is affected by its whole set of relations with other literature in its tradition and in its own moment.

Bakhtin, in a specifically twentieth-century extension of Marx that responds to Saussure, argues:

The problem of the interrelationship of the basis and superstructures ... can be elucidated to a significant degree through the material of the word. ... The essence of this problem comes down to how actual existence (the basis) determines sign and how sign reflects and refracts existence in its process of generation.... The word is the medium in which occur the slow quantitative accretions of those changes which have not yet achieved the status of a new ideological quality, not yet produced a new and fullyfledged ideological form. The word has the capacity to register all the transitory, delicate, momentous phases of social change. (19)

What Bakhtin prescribes here is a kind of Marxist philology - a relentless attention to historical shifts in the meanings of words which is sensitive to the ideological, political, and social dimensions-aspects that in fact the best classical philologists, for all their Hegelian idealism, have explored richly.

The Soviet official theorists against whom Bakhtin was reacting subsumed this whole area under the rubric "social psychology." Accordingly, Bakhtin attempted a strategic redefinition: 
It follows that social psychology must be studied from two different viewpoints: first from the viewpoint of content, i.e., the themes pertinent to it at this or that moment in time; and second, from the viewpoint of the forms and types of verbal communication in which the themes in question are implemented. ... This issue of concrete forms has significance of the highest order. . . . Each period and each social group has had its own repertoire of speech forms for ideological communication in human behavior. Each set of cognate forms, i.e., each behavioral speech genre, has its own corresponding set of themes. An interlocking organic unity joins the form of communication ... the form of the utterance ... and its theme. (20-2 1$)$

Bakhtin's intense focus here on the tight linkage between the ideological content and the specific form of communication implies a serious politics of forms, of genres, which it is a central goal of the following chapters to elaborate. Here I underline the decisive shift in emphasis this linkage implies from simple determination by the base toward explorations of the mediations intrinsic to the process of ideological communication.

In exploring how the texts under consideration actually function within Greek society and the ways that process is potentially meaningful for us, Gramsci offers the most broadly useful conceptual framework. Fundamental to Gramsci's thought is the distinction between dominance and hegemony. ${ }^{47} \mathrm{~A}$ dominant class is able to impose by force its will on the dominated classes. But, in fact, Gramsci argues, no regime remains in power exclusively by brute repression except in periods of revolution.

Every dominant class seeks to become hegemonic; that is, it seeks to achieve supreme moral and intellectual authority in the minds of all classes or, in Lyndon Johnson's notorious phrase, to "win the hearts and minds of the people." Gramsci thus focuses central attention on the role of intellectuals and cultural production in class struggle. A

\footnotetext{
${ }^{47}$ Gramsci argues, "We can . . f fix two major superstructural 'levels': the one that can be called 'civil society' (that is, the ensemble of organisms commonly called 'private'), and that of 'political society' or 'the State'. These two levels correspond on the one hand to the function of 'hegemony' which the dominant group exercises throughout society and on the other hand to that of 'direct domination' or command exercised through the State and 'juridical' government. ... The intellectuals are the dominant group's 'deputies' exercising the subaltern function of social hegemony and political government. These comprise: 1 . The 'spontaneous' consent given by the great masses of the population to the general direction imposed on social life by the dominant fundamental group; this consent is 'historically' caused by the prestige (and consequent confidence) which the dominant group enjoys because of its position and function in the world of production. 2. The apparatus of state coercive power which 'legally' enf orces discipline on those groups who do not 'consent' either actively or passively. This apparatus is, however, constituted for the whole of society in anticipation of moments of crisis of command and direction when spontaneous consent has failed" (1971: 12).
} 
dominant class needs effective intellectuals to stay in power. A challenging class that has succeeded on the level of moral and intellectual authority is in the best position to displace a dominant class. This is not to reinstate the illusions of the young Hegelians that "reforming consciousness" will alone and of itself transform society. Gramsci, like Marx, recognizes that there are situations in which the metaphorical weapon of criticism must be supplemented by the metaphorical criticism that consists in weapons. But, as Marx puts it, "material force must be overthrown by material force; but theory also becomes a material force as soon as it has gripped the masses" ("Contribution to the Critique of Hegel's Philosophy of Law: Introduction," MECW 3:182). What Gramsci adds is a richer elaboration of the subtle and complex range of social mechanisms by which contending forces in society struggle to seize the minds and hearts of the masses. Gramsci's analytical framework insists on the centrality of all intellectual production to class struggle, whether (to echo the Communist Manifesto) "open or hidden." Moreover, as Fredric Jameson has pointed out (1981: 287; Said 1983: 171 ), a genuine appreciation of the concept of hegemony implies severe limitations on a simple coercive, manipulative, or functionalist conception of culture. Culture for Gramsci is by its very nature an attempt at persuasion, a form of rhetoric. As Said puts it, "well before Foucault, Gramsci had grasped the idea that culture serves authority, and ultimately the national State, not because it represses and coerces but because it is affirmative, positive, and persuasive" (1983: 171).

Althusser's major contributions in this area are, for my purposes, four. First, he has elaborated Gramsci's focus on struggle in the ideological sphere by examining the specific material social institutions-what he dubs the "ideological state apparatuses" (1971: 127-86) - which, as opposed to the more familiar "repressive state apparatuses" (police, courts, army), systematically attempt to reproduce in the consciousness of each individual spontaneous consent to those relationships of dominance and subordination that perpetuate the status quo. He cites, for example, such institutions as the church, the educational system, the mass media, cultural entities, and political parties.

Second, Althusser's notion of "interpellation"-from the Latin interpellare, "to accost," "to hail" someone (1971: 170-83) 4 $^{8}$-has given far greater precision to the mechanisms by which ideological practice so-

\footnotetext{
${ }^{48} \mathrm{As}$ it happens, this is the least common sense of the Latin verb, which most of ten has the sense of "interrupt" or "obstruct"-connotations quite alien to the largely unconscious process envisioned by Althusser.
} 
cially constructs individual identity. By summoning individuals to spontaneous assent and concrete forms of behavior (e.g., saluting the flag, genuflecting before the altar, deferring to or abusing women) or to a proffered identity ("we French," "we Catholics," "we men"), ideological apparatuses attempt to instill a totally unconscious acceptance and practice of the social relations of the status quo as entirely natural.

A third contribution of Althusser to contemporary Marxist analytic discourse is his polemical defense of a Marxist appropriation of Freud (1971: 189-219). To be sure, he was not the first, and we look subsequently at the very different articulation between Freud and Marx effected by the Frankfurt School. Althusser lays primary stress on "the unconscious and its 'laws'" (204), on “'mechanisms' and 'laws' of dreams" (207). Following Lacan's appropriation of Jakobson's enormously influential elaboration of metonymy and metaphor, Althusser endorsed the reduction of Freud's analysis of these mechanisms to two: displacement and condensation (207) ${ }^{49} \mathrm{He}$ argues, perhaps too forcefully, for the independence of psychoanalysis in terms that in fact have a broadly anthropological thrust: "History, 'sociology,' or anthropology have no business here, and this is no surprise for they deal with society and therefore with culture, i.e. with what is no longer this small animal-which only becomes human-sexual by crossing the inf inite divide that separates life from humanity, the biological from the historical,

49I find this move unfortunate. The sixth chapter of Interpretation of Dreams (Freud 1958-74: $5: 277-338,6: 339-508$ ), on the dreamwork, is widely recognized as Freud's most brilliant. In particular, his analysis of the grammar of dreams, the problems of representability and symbolism, should not be subsumed under the first two mechanisms he discusses (i.e., condensation and displacement). The point is of concern to me because one of the most progressive attacks on Freud in the field of classics (duBois 1988) focuses exclusively on the ancient symbolization of women in the light of Freud's account of women as symbolically castrated males. Although duBois of fers a trenchant critique of Freud's appropriations of ancient Greek myth and elaborates a compelling case for an alternative symbolization of women in ancient Greece, she does not address the issue of the unconscious and its mechanisms as such. It is one thing to historicize Freud by demonstrating that different cultures symbolize sexual difference in significantly different ways - ways that in part reflect their economic structure. It is quite another to contend, as duBois does, that "the weight of Freud's insight is lost if we abandon the theory of castration, which is indissolubly linked to the description of sexual difference. Little boys would not fear castration, would not resolve their Oedipus complex, if they did not know of the existence of 'the other,' the castrated sex" $(1988: 12)$. Such an analysis, if I read it rightly, seems to preclude the symbolic representation in ancient Greek texts of male fears of castration-not to mention the representation of Oedipal conflict. Since I find both quite prevalent, I can only conclude that we need a better account of what is involved in historicizing the products of the unconscious. I have long been struck by the anthropological plausibility of Crews's distillation of Freud's view of a human being as "the animal destined to be overimpressed by his parents" (Crews 1970: 12). This seems to me to be valid regardless of how that overestimation manifests itself symbolically. 
'nature' from 'culture" (206). Whereas he only glances defensively at the substantial problems implicit in historicizing Freud (211 n. 4 and 217 ), Althusser insists rightly on the central relevance of Freud to "all investigations into ideology" $(219) .^{50}$

Finally, Althusser's concept of "structural determination" or, borrowing from Freud, "overdetermination" goes a long way toward liberating Marxist discussions of base and superstructure from both the procrustean bed of Stalinism (or, to use Althusser's term, "arthritis") and the circularity of a purely Hegelian version of dialectic. ${ }^{51}$ Mechanistic causality of the Stalinist variety has too of ten presented the superstructure as a sort of baseball impelled by the bat of technology and other purely mechanical economic factors. ${ }^{52}$ Hegel, to whom antiStalinists such as Lukács and the Frankfurt School were inevitably drawn, "solves" the relation of the part to the whole by positing the same substance, Geist (soul/mind), undergoing the same immanent developments at all levels. In effect, the whole of reality is conceived in ways that bear a distinct similarity to what Foucault (1970: 17-25) has analyzed as the Renaissance/medieval epistēme- as a series of correspondences, though to be sure the Hegelian ones are all, so to speak, Geist. For Hegel the passage of the world spirit from natural consciousness to alienation to full self-consciousness corresponds to the development of each individual and in turn to the movement of all history. Althusser's model, like Bakhtin's, stresses the relative autonomy of various spheres-economic, political, cultural-which operate in accordance with their own specific laws but at the same time are incessantly and deeply interactive. Thus the serious exploration of the causes of any significant phenomenon (he uses as his example the Russian Revolution) reveals that each component is determined by and itself determines a multiplicity of other phenomena-much as an element in a dream turns out, on analysis, to have a multiplicity of determinants while its presence in the dream itself affects all the other elements. ${ }^{53}$

Despite the subtlety and usefulness of Althusser's analyses, despite his own recognition of the cultural sphere as "the site of class struggle"

\footnotetext{
${ }^{50}$ For a more detailed and nuanced discussion of Althusser's use of Freud and Lacan in the analysis of ideology, see Paul Smith 1988: 18-23 and Barrett's second thoughts in her new introduction to Women's Oppression Today (1988: xv).

${ }^{51}$ The best statement is in "Contradiction and Overdetermination" (Althusser 1969: 87-128). See also "Marx's Immense Theoretical Revolution" (Althusser and Balibar 1970: 182-93).

${ }^{52}$ Here I disagree with Fredric Jameson (1981: 37 and n. 19) in seeing "Hegel" as the codeword for Stalin, since the model of changes in production driving the whole process of change is, to my mind, a perfect example of bat-strikes-ball mechanical causality.

${ }^{53}$ For the link between Althusser's and Freud's uses of overdetermination, see Althusser's appendix "Freud and Lacan" (1971: 189-219) as well as the translator's useful glossary in Althusser 1969 (s.v., 252-53).
} 
(1971: 147), Althusser has been rightly criticized for of fering too pessimistic a picture of the process of ideological reproduction (Giroux 1983: 263-64; Paul Smith 1988: 18). The status quo seems to have all the advantages in its ceaseless and relentless brainwashing of passive subjects, whom Althusser presents precisely as "subjected" to reigning hegemonic ideas.

\section{Jameson: The Double Hermeneutic and the Utopian Impulse}

Fredric Jameson, whose name I invoke partly as a shorthand for all the insights of the Frankfurt School he has done so much to bring to English-speaking readers (esp. 1971), offers, in my view, the single most relevant critical model for a Marxist reading of the classics. Not only are his central concepts more deeply in tune with the liberatory thrust of Marx's own work; Jameson's more openly dialectical conception of the process of ideological struggle offers the most meaningful way out of the depressing either/or designation of particular classical authors as "good guys" or "bad guys" which has, as noted earlier, characterized much of previous Marxist or even loosely political readings of the classics. Moreover, though his own work has largely ignored issues raised by feminists, his critical model has been fruitfully appropriated for a feminist analysis of contemporary cultural production. ${ }^{54}$

The critical concept in Jameson which seems to me most decisive in opening classical texts to the fullest Marxist reading is his notion of a double hermeneutic. The idea of a hermeneutic in general has nothing uniquely Marxist about it. Leaving aside its Aristotelian sense and its role in biblical exegesis, Jameson focuses on the medieval Christian interpretive enterprise: the Christian hermeneutic incorporates alien cultures and philosophies by demonstrating through a kind of translation their underlying (unconscious) anticipations of Christianity (197 1: 84). ${ }^{55}$ Vergil (that anima naturaliter Christiana) has perhaps been

${ }^{54}$ The finest example I am aware of is Modleski's brilliant application (1982) of an explicitly Jamesonian double hermeneutic to Harlequin romances, Gothic novels, and television soap operas.

55The argument on hermeneutics is far more tortuous in chap. 1 of Political Unconscious because, as Jameson notes, "it is . . increasingly clear that hermeneutic or interpretive activity has become one of the basic polemic targets of contemporary poststructuralism in France" (1981: 21$)$. The hermeneutic model elaborated there returns to the notion of allegory on four levels (cf. 29-33) which he first explored apropos of Walter Benjamin (Jameson 1971: 6o-61). See also his fuller elaboration of the relation of Marxism to Christianity (1971: 117-18). For my purposes, the older "double" model is 
the most frequent subject of this approach. ${ }^{56}$ A classicist may say cynically, "better to Christianize Vergil than to burn his poems," but object that any such interpretive enterprise is a hopeless distortion. But the Vergil of modern classical literary scholarship is fully and necessarily as remote from the Vergil appropriated by the original audience as is the Christianized Vergil. The most professedly antiquarian Vergil scholar (in the sense described earlier) is not really content to refuse all claims of relevance for this text. Yet relevance implies some hermeneutic operation, some interpretive recasting or translation of the apparently alien elements into an accessible form. The hermeneutic enterprise has long been, to this extent, the humanistic alternative to iconoclasm in its most brutal and irreversible forms. Totalizing systems that lack this hermeneutic impulse are capable-alas, whether they are leftist or rightist-of burning books. ${ }^{57}$ As Adorno said in denouncing the Stalinist approach to cultural criticism, "they lack the experience of that with which they deal. In wishing to wipe away the whole as with a sponge, they develop an affinity to barbarism" (1981: 32$)$.

Whereas Jameson is entitled to invoke older sorts of hermeneutic appropriation as a warrant for his own enterprise, I stress the fact that the peculiarly dialectical form of his hermeneutic-what makes it "double"-is the distinctive feature of Marx's own general approach to social and historical phenomena. Here it is worth recalling Marx's claim that with Hegel the dialectic "is standing on its head. It must be turned right side up again, if you would discover the rational kernel within the mystical shell" (Capital, 1967:1:20). The same hermeneutic characterizes Marx's interpretation of capitalism itself. Edmund Wilson long ago (1940) gave a wonderfully readable account of the many other socialist critics of capitalism in the nineteenth century, both prior to and contemporaneous with Marx. A distinguishing feature of Marx, of ten offensive to some of his allies, was his repeated emphasis on the progressive features of capitalism as an integral part of his indictment of its regressive aspects. There is, for example, a kind of preamble to the utopian vision of the "realm of freedom" in the passage we quoted earlier from the unfinished third volume of Capital. Marx there de-

more serviceable; and, I would say, the best readings of Political Unconscious still adhere to it.

${ }^{56}$ See Comparetti (1908: esp. chaps. 5, 7, and 8) and Knight, who notes-with what we can today recognize as undue optimism-apropos of Servius that he is "already inclined to the allegorical kind of interpretation which was later to reach almost the greatest depths of absurdity that the human mind has attained" (1954: 308).

${ }^{57}$ Lest this comment be taken too readily as the self-congratulation of a traditional liberal, I remind the reader of America's own pernicious capacity for book burning and more recently phonograph-record-burning. For an historical meditation on bookburning, see Lowenthal $1987-88$. 
clares: "It is one of the civilizing aspects of capital that it enforces this surplus labour in a manner and under conditions which are more advantageous to the development of the productive forces, social relations, and the creation of the elements for a new and higher form than under the preceding forms of slavery, serfdom, etc." (1967:3:819). Capitalism, in which exploitation, human alienation, and greed are structural components, is also by its very nature the most social form of production; and its very logic of accumulation prepares the way for a more civilized mode of production and social relations. This hermeneutic operation avoids both nostalgia and despair by a utopian extrapolation from the dynamic potentialities of the brutal present in its full complexity.

Jameson introduces a more rigorous conception of the dual aspect of hermeneutics by reference, not to Marx, but to a modern theologian, Paul Ricoeur. Ricoeur uses the terms "negative and positive hermeneutics" to designate a hermeneutic directed at demystification, at the destruction of illusions, and a hermeneutic that "restores to access some essential source of life" (Ricoeur 1970: 27-36; cf. Jameson 197 1:1 19). Ricoeur himself refers to an implicit double hermeneutic in the thought of Marx, Nietzsche, and Freud. Though each was a master of the negative "hermeneutics of suspicion," their commitment to the demolition of false consciousness involved the aim of extending and liberating consciousness.

Jameson explores (1971: 120-59) a more explicitly Marxist sense of the double hermeneutic in the work of Ernst Bloch $5^{5}$ but in varying degrees this hermeneutic enterprise characterizes all the so-called Frankfurt School of Marxists: Adorno, Horkheimer, Benjamin, and (most familiar to Americans) Herbert Marcuse. My description of this Marxist hermeneutic is thus necessarily a somewhat eclectic fusion of these figures' views and Jameson's own impressive contribution.

For the Marxist, the task of the negative hermeneutic requires a rigorous, even ruthless elucidation of all the aspects of the work of art which reveal its active ideological support for the status quo-regardless of the artist's conscious intentions. The fundamental Marxist assumption (here, as in the positive hermeneutic) is that Western society has always been characterized by class struggle, "sometimes open, sometimes hidden." A second assumption for the negative hermeneutic is, as we recall from the German Ideology, that "the ideas of the

${ }^{58}$ At the time Jameson wrote Marxism and Form, virtually none of Bloch's work was available in English apart from occasional excerpts or essays in New German Critique and Telos. But now, in addition to Zipes's collection of Bloch's essays (1988), Bloch's massive chef d'oeuvre, Principle of Hope, as well as his Natural Law and Human Dignity have appeared in English (1986a; 1986b). 
ruling class are in every epoch the ruling ideas; ... the ideas of those who lack the means of mental production are on the whole subject to it" $(M E C W$ 5:59). Most Western art proclaims in various ways its allegiance to the ruling classes that by and large have sponsored it. It does not, however, simply reflect passively a static image of human existence, of social, psychological, political, and economic structures perpetrated by those ruling classes. Insofar as it is ideologically partisan, it seeks actively to contain and mystify the sources of discontent that are directed against the status quo. The oppositional voices that are responded to without an open opportunity to state their own case in their own terms constitute a "structured silence" (Macherey 1978) in the text and leave only traces or symptoms. Art, insofar as it functions as ideology, implies the impossibility or undesirability of alternatives to the status quo and thus defends the ruling-class version of reality as the only reality conceivable. Jameson adopts from Freudian Norman Holland (1968) the term "manage" to describe the functioning of ideology in the unconscious:

This concept allows us to think repression and wish-fulfillment together within the unity of a single mechanism, which gives and takes alike in a kind of psychic compromise or horse-trading, which strategically arouses fantasy content within carefully symbolical containment structures which defuse it, gratif ying intolerable, unrealizable, properly imperishable desires only to the degree to which they can again be laid to rest. (1979c: 141)

He sees this form of managing as especially appropriate to art under commodity capitalism. Yet Lévi-Strauss's analysis of preliterate myth as a mechanism for managing insoluble contradictions suggests that this process may be a general feature of all ideology: "The purpose of myth is to provide a logical model capable of overcoming a contradiction (an impossible achievement if, as it happens, the contradiction is real)" (1967: 226). This sort of management of real contradictions by supplying imaginary resolutions serves the status quo.

The specifically Marxist positive hermeneutic aims at restoring to consciousness those dimensions of the artwork which call into question or negate the ruling-class version of reality. Here one might object that there is no inherent necessity of a double hermeneutic for every work of art, because some art (Pindar, for example, seems an obvious instance) is all on one side of the struggle. Yet, even if one concedes that the ideological function of art is in some sense to manage potentially disruptive discontents within society, then by definition art cannot manage what it does not in some way reveal and evoke. The very aim 
of management or containment implies the acknowledgment that what is "passed over in silence" (Pindar Ol. 9.103) must in some sense be present as the political unconscious of the text. Moreover, as noted above, the Gramscian conception of ideological warfare presupposes a process more of persuasion than of simple, mechanistic manipulation. To put it another way, the audience may refuse the intended solution and respond rather to the unavoidable reminder of its sources of discontent.

As Paul Smith has recently argued, even ideological interpellation, outlined by Althusser as a rather mechanistic process of constructing an obedient "subjected subject" of ideology, lends itself to a process somewhat akin to Jameson's psychic horsetrading. The multiplicity of interpellations, particularly in a period of radical change in the basic structures of society, opens a space of resistance to some interpellations and a corresponding choice of alternative roles for the subject, precisely because the subject positions of fered by ideology are contradictory (Paul Smith 1988: 25).

Moreover, argued those of the Frankfurt School, art cannot be reduced solely to ideology-however crucial it is to analyze its ideological roles. Authentic art by its nature involves a re-creation of and distancing from the ordinary reality of experience: "With its built-in Verfremdungs-Effekt', its intrinsic estrangement from reality, art will always preserve in sensuous representation the suprahistorical themes of life, the image of unactualized potentialities" (Katz 1982: 201-202). Insof ar as artistic form subjects the reigning version of reality to art's own laws of coherence and beauty, it constitutes a critique, a negation and a utopian transcendence of that reality. These laws are, to be sure, like Marx's economic laws, historically determined and specific to particular social formations. But, as Marx also recognized, they are not in any simple lockstep with the laws of the economic base (Solomon 1979: 6164).

Jameson, following Marcuse, brings out nicely the apparent harmony of this concept with more traditional idealist aesthetics by citing Schiller, who in the heat of the French Revolution turned to the study of aesthetics. "I hope to convince you," Schiller wrote, "that it is precisely the path through the aesthetic question that we are obliged to take in any ultimate solution of the political question, for it is through beauty that we arrive at freedom" (Jameson 1971: 86). Marcuse, whose work represents the most comprehensive Marxist appropriation of Freud, explicates Schiller as follows:

The play impulse is the vehicle of this liberation.... It is the play of life itself, beyond want and external compulsion-the manifestation of an 
existence without fear and anxiety, and thus the manif estation of freedom itself. Man is free only when he is free from constraint, external and internal, physical and moral-when he is constrained neither by law nor by need. But such constraint is the reality. Freedom is thus, in a strict sense, freedom from the established reality. $(1974: 187)$

Marx's own lifelong quest for human freedom as full autonomy and historically constructed sensuous gratification here meets with a politicized and historicized Freud. Marcuse sees in Schiller's play impulse the psychic drive toward total gratification which is constantly repressed by the mechanisms of society. Freud tended to view the drives of the pleasure principle as literally childish and social repression as the inevitable price of maturity. But Marcuse and the Frankfurt School generally tend to view positively the restless discontent inspired by the thwarted pleasure principle; it is a source of revolutionary energy constantly threatening the constraints of the status quo-the very principle of hope, driving humanity forward toward the realm of freedom and negating all form of unfreedom, whatever political label unfreedom may claim.

In his historicization of Freud, Marcuse further argues that Western societies have always been characterized by what he calls "surplus repression"-repression beyond that necessary to carry out the work of social survival. Further, the necessary repression has not been shared equitably in class societies; a small elite has always enjoyed a disproportionate access to gratification (1974: $37-46)$. The positive hermeneutic reveals the liberating potential of this imbedded vision of gratification as a potential source for "educating the five senses"available now to a wider audience.

Marcuse's own early analysis of "affirmative culture" (1969; the essay first appeared in Germany in 1937) is not only a usef ul example of the double hermeneutic in action but also a salutary caution that, when a Marxist speaks in praise of art, something very different is at work from the kind of praise lavished on the classics by an Allan Bloom or a William Bennett. Indeed, Marcuse's analysis of the ambiguity of art and culture in Nazi Germany has some distressing affinities with the crisis of the classics alluded to earlier. Starting with Aristotle's division of life into business and leisure, parallel with a division between what is usef ul and what is beautiful (ta kala), Marcuse argues that "the ancient theory of the higher value of truths above the realm of necessity includes as well the 'higher' level of society. For these truths are supposed to have their abode in the ruling social strata" $\left(9_{1}\right)$. Bourgeois society instead offers a theory in which there is no acknowledged higher stra- 
tum of society: instead we get "the thesis of the universality and universal validity of "culture"" (93). The decisive characteristic of this specifically bourgeois affirmative culture is "the assertion of a universally obligatory, eternally better and more valuable world that must be unconditionally affirmed: a world essentially different from the factual world of the daily struggle for existence, yet realizable by every individual for himself 'from within,' without any transformation of the state of fact" (95, emphasis added).

Marcuse argues that a peculiar development of the notion of "soul" is essential to affirmative culture, a view of soul which "means precisely what is not mind" (107): "an essential difference between the soul and the mind is that the former is not oriented toward critical knowledge of truth" (112). It is tempting here to recall Allan Bloom, who on the one hand informs us categorically that "there is no real teacher who in practice does not believe in the existence of the soul" (1987:20) but on the other has little room in his own educational vision for genuinely critical thinking.

The darkest indictment Marcuse levels at this affirmative culture of the soul is its complicity in the success of Nazism: "High above factual antithesis lay the realm of cultural solidarity. ... The individual is inserted into a false collectivity (race, folk, blood, soil)... . That individuals freed for over four hundred years march with so little trouble in the communal columns of the authoritarian state is due in no small measure to af firmative culture" (125). In terms particularly relevant to the contemporary appropriation of the classics, Marcuse continues: "The new methods of discipline would not be possible without casting off the progressive elements contained in the earlier stages of culture" (125-26); that is, unless the classics are divested of their liberatory moments, they cannot serve the purposes Bloom and Bennett have in mind for them.

But even bourgeois affirmative culture, this seemingly irredeemable evil of capitalist society, is in fact also subjected to a positive hermeneutic by Marcuse:

There is a kernel of truth in the proposition that what happens to the body cannot affect the soul. But in the established order this truth has taken on a terrible form. The freedom of the soul was used to excuse the poverty, martyrdom, and bondage of the body. ... Correctly understood, however, spiritual freedom does not mean the participation of man in an eternal beyond where everything is righted when the individual can no longer benefit from it. Rather, it anticipates the higher truth that in this world a form of social existence is possible in which the economy does not preempt the entire life of individuals. (109) 
In a hidden and distorted form, affirmative culture, for all its cooptive intentions, cannot fail to open a realm in which the status quo is negated:

The soul really is essential-as the unexpressed, unfulfilled life of the individual. ... There is a good reason for the exemplification of the cultural ideal in art, for only in art has bourgeois society tolerated its own ideals and taken them seriously as a general demand. What counts as utopia, phantasy, and rebellion in the world of fact is allowed in art. There affirmative culture has displayed the forgotten truths over which "realism" triumphs in daily life. (114)

The beauty associated with art and the apparent vehicle by which it lulls and seduces contains a deeply subversive aspect:

Even beauty has been affirmed with good conscience only in the ideal of art, for it contains a dangerous violence that threatens the given form of existence.... The immediate sensuousness of beauty immediately suggests sensual happiness.... Beauty is fundamentally shameless.... It displays what may not be promised openly and what is denied the majority. (115)

It is clear from Marcuse's analysis that essential to the double hermeneutic - what makes it work and carries us past the momentarily confusing shifts of "negative," "positive," and "affirmative"-is its dialectical character in which the notion of internal contradiction is central. Affirmative culture can turn into its own negation because it is founded on a contradictory impulse inherent to capitalism, namely, the desire to win adherence by claiming for the whole of society an access to gratification which it can structurally grant only in a distorted form to a few. For this reason, the double hermeneutic in its strongest sense is available as an analytic tool only to those who take a stand against that injustice, who find positive whatever negates the injustice of the status quo.

Jameson's version of this duality is equally founded in a notion of the inherent contradictions of class society. All class ideology, he argues, is simultaneously self-serving ideology and the projection of a utopian image precisely because it projects a vision of the ruling class as an ideal community $(1981: 290-91) .{ }^{59}$ Only someone who has become

${ }^{59}$ Cornel West is harsh in his denunciation of this statement: "This exorbitant claim not only illustrates a utopianism gone mad, but also a Marxism in deep desperation, as if any display of class solidarity keeps alive a discredited class analysis" (1982b: 195). He goes on to characterize it as "Marxist flights of optimism ... an American faith in the 
aware of the contradictions of the society as a whole can both demystify the ideology and appropriate the vision as a prefiguration of that real community only truly possible in a society free of the exploitation of one class by another. On the other hand, the specific means by which a particular literary work may both manifest its historical moment and open a utopian dimension are not susceptible to a priori techniques of interpretation. As Jameson rightly argues, "there can be no preestablished categories of analysis: to the degree that each work is the end result of a kind of inner logic or development of its own content, it evolves its own categories and dictates the specific terms of its own interpretation" (1971: 333). So too against the simple socialist judgmental "barbarism" Adorno invokes

immanent criticism as the more essentially dialectical. ... It takes seriously the principle that it is not ideology in itself which is untrue but rather its pretension to correspond to reality. Immanent criticism of intellectual and artistic phenomena seeks to grasp, through the analysis of their form and meaning, the contradiction between their objective idea and that pretension. (Adorno 1981: 32)

The approach of the Frankfurt School thus precludes a simple value judgment based exclusively on explicit political content. Rather, it compels us to deal fully with the epistemology of artistic form, to see the particular genre-the epic, the ode, the tragedy-not as a simple reflection of the reality defined by the Greek aristocracy but as a largely autonomous transformation of and response to aesthetic as well as political realities, that is, the specific available literary tradition, circumstances of dissemination, and reception. Its relative autonomy is an inevitable consequence of its formal, sensuous aspects-the fact that it is enmeshed in a whole range of signif ying systems such as meter, music, all the conventions of the specific genre as well as the entire Greek poetic and ritual tradition, all of which constitute in various ways intractable interference to unmediated reflection.

A related topic is the relative weight in any particular work of art of these two voices elicited by the double hermeneutic. Is there a

future" (196). This indictment misses the point of a double hermeneutic and precludes any serious, much less sympathetic, exploration of the deeper roots of the mass appeal of ideologies that are repellent in their practical consequences. Yet the whole project of the Frankfurt School is to understand the success of the Nazis in winning such widespread adherence to beliefs and policies which a less dialectical Marxism saw simply as contrary to the objective interests of the German working class. In this connection, it is worth remembering that-whatever the importance of Lukács for Jameson (West 1982b: 178)-Marcuse, whose scathing analysis of affirmative culture I have quoted at length for just this reason, was for some ten years Jameson's colleague and close friend. 
specifically aesthetic value judgment based on this sort of analysis? Is a work of art better, because its formal aspects more intensively call into question the status quo, than a work that tends both in form and content to reinforce the status quo? The answer of the Frankfurt School Marxists seems to be a somewhat equivocal yes. As Adorno puts it, "a successful work ... is not one which resolves objective contradictions in a spurious harmony, but one which expresses the idea of harmony negatively by embodying the contradictions, pure and uncompromised, in its innermost structure" (1981: 32). Whereas Marx himself, Engels, and in this century Lukács tend rather to invoke the highly problematic criterion of a work's truth to reality, this immanent critique values a certain lack of closure in a work, the chinks that allow us a glimpse of its political unconscious, the contradiction between its ideology and its traces of the real. But is this not, after all, what Marx and Engels so admired in Balzac?

In any case, the richness of a work of art seems a direct function of the tension between its commitment to a class-bound version of reality and its aesthetic capacity to open wider horizons, to set its own ideology in an inherently richer and freer aesthetic and cognitive context. Jameson succeeds in fusing the divergence between the Frankfurt School and the more traditional Marxist valorization of realism in the following methodological proposition:

Great art distances ideology by the way in which, endowing the latter with figuration and with narrative articulation, the text frees its ideological content to demonstrate its own contradictions; by the sheer formal immanence with which an ideological system exhausts its permutations and ends up projecting its own ultimate structural closure. (1979a: 22-23)

This dense formulation does not posit a simple opposition between an essentialist aesthetic effect and a negatively conceived ideological effect (Lewis 1983; Paul Smith 1988: 27-29). Rather, it posits in the gap between the working out of an artistic form's own potentialities and the working out of an ideology's various strategies of containment and closure the cognitive possibility of exposing the limits of ideology.

In turning now to selected classical texts, I attempt to open these allegedly univocal repositories of elitist, misogynist, and racist ideology and permit other voices to speak. In historicizing their self-serving utopian visions, I hope also to suggest how the historically transformed ear of the modern audience may appropriate the cry of freedom, the invitation to a just community, and the promesse de bonheur. 